\title{
MÚKÖDÉSI ZAVAROK ÉS MEGÚJULÁSI TÖREKVÉSEK A TUDOMÁNYOS PSZICHOLÓGIÁBAN, A 21. SZÁZAD ELEJÉN
}

\author{
SZOKOLSZKY ÁGNES
}

Szegedi Tudományegyetem, Pszichológiai Intézet, Kognitív és Neuropszichológiai Tanszék

E-mail: szokolszky@gmail.com

Beérkezett: 2018. február 1. - Elfogadva: 2018. október 18.

\begin{abstract}
A 2010-es évek elején a tudományos pszichológiában kibontakozó müködési zavarok és válságérzet (a tudományos csalások és visszavont publikációk számának megnövekedése, a vitatható kutatási eljárások, a gyenge vagy kétséges cikkek megjelenése vezetô folyóiratokban, és a tudományos kommunikáció torzulásai) a Brian Nosek és munkatársai nevével jelzett „Megismétlési Projektben” (2011-2015) csúcsosodtak ki, egyfajta bizalmi válságot hozva létre. A pszichológiának szembe kellett néznie (más tudományágakkal együtt) a kutatási eredmények validitását és megbizhatóságát érintô problémákkal. Az alapos önvizsgálat sokféle nem feltétlenül új keletú - hiányosságot tárt fel, amelyek különbözö mértékben érintették a különbözố kutatási területeket. Ilyen volt a pontos megismétlések hiánya, a konceptuális megismétlések visszásságai, a kutatói hipotézist nem igazoló negatív eredmények mostoha státusza, és az ezzel járó publikációs torzulás, a kutatói hipotézist alaptalanul megerösitố (hamis pozitív) eredmények elterjedtsége, és a nullhipotézis-teszteléssel és a statisztika alkalmazásával kapcsolatos korántsem új kritikák. A 2010-es évek vége felé már megfeleló rálátásunk van a feltárt problémákra, jobban értjük az okokat és háttértényezóket, és új megoldási módok és ajánlások is megfogalmazódtak. E tanulmányban a válság fö okainak, szimptómáinak és tanulságainak áttekintésére vállalkozom, és a kibontakozó reformmozgalom nyomán jelentkezó új eljárásokra és ajánlásokra hivom fel a figyelmet. A pszichológia e válságperiódusban bizonyította önkorrekciós képességét. A kutatási és publikációs gyakorlatot a jobb múködés irányába mutató impulzusok érik, de ezek hatása csak úgy tud érvényesülni, ha a kutatók mint egyének és mint kutatói közösségek tudatosabban viszonyulnak a problémák megoldásához.
\end{abstract}

Kulcsszavak: adatmanipuláció, Megismétlési Projekt, megismétlési válság, metodológiai reformmozgalom a pszichológiában, publikációs gyakorlat, tudományos csalás, elfogadhatatlan kutatói viselkedés, nullhipotézis-tesztelés 
A pszichológia történetében nem ismeretlen jelenség a krízis és az önvizsgálat. A válság érzete lényegében a tudományos pszichológia megalakulása óta kísért, amikor is egymással vitázó nézôpontok fogalmazódtak meg az új tudomány tárgyára, módszertanára és emberképére nézve. Nem egyértelmú azonban az, hogy mit tekintsünk válságnak. Egy nézet szerint a pszichológia alapvetően válságban levô tudomány, mert széttöredezett elméleti keretek és módszertani irányzatok jellemzik, és kevés jele van a humán jelenségek átfogó, belsô ellentmondásoktól mentes megértésének (vö. Dilworth, 2008). Más megközelítésben az egységes és konzisztens pszichológia ideálja irreális, és sokkal gyakorlatiasabb kritériumokat kell felállítani: akkor áll fenn válság, ha elméleti és módszertani eszközeinkben és eljárásainkban olyan hibák fordulnak elô, amelyek súlyosan hátráltatják vagy akadályozzák a feladatok ellátását (Zittoun, Gillespie és Cornish, 2009).

Nem idealizmus azt állítani, hogy minden tudomány alapvetô feladata az, hogy érvényes és megbízható tudást állítson elô, és megkérdôjelezhetetlen legyen etikai integritása. Ha ezekkel a kritériumokkal szemben merülnek fel kétségek, az feltétlenül kimeríti a válság pragmatikus feltételeit, és kiemelt figyelmet érdemel.

A 2010-es évek közepén több jel szerint egy olyan tényleges válság alakult ki, amelyik a tudományos pszichológia múködésének alapjait érintette. A jelzések többféle irányból érkeztek. Az ezredfordulót követôen feltûnô módon megszaporodtak az etikailag megkérdôjelezhetô eljárásokról és tudatos kutatási csalásokról (adathamísításokról, adatmanipulációkról) szóló beszámolók. Az évtized elején legismertebbé vált „elfogadhatatlan kutatói viselkedés” („scientific misconduct”) eset Diederik Stapelt, a holland Tilburg Egyetem kutatóját érintette. Az évtized vége felé Brian Wansink, a nagyhírú amerikai Cornell Egyetem kutatója körül keletkezett botrány keltett nagy figyelmet (van der Zee, 2017), de a két kutatón kívül számos esetre derült fény, és újabb és újabb esetek derülnek ki (vö. Randall és Welser, 2018).

A gyakran vezetô kutatókat érintô esetekkel kapcsolatos vizsgálódások mentén felmerült: lehetséges, hogy ezek csupán a jéghegy csúcsát jelentik. Neves szaklapokban megjelent nehezen hihetô, illetve megismételhetetlennek mutatkozó eredmények jelezték a problémák sokrétûségét. A baj érzetét növelte annak tudatosulása, hogy a pszichológiai kutatásban és a publikációs gyakorlatban széles körben elterjedtek vitatható gyakorlatok. Ehhez váratlanul hozzáadódott még az is, hogy a kutatói integritást is érintô kritika bontakozott ki a pszichológia egyik klasszikus kísérletével: a stanfordi börtönkísérlettel szemben is (lásd Szokolszky, 2018).

A vizsgálódások és kétségek egyfajta bizalmi válság megfogalmazódásához vezettek az empirikus kutatások egy részének érvényességével és megbízhatóságával kapcsolatban. Bizonytalanság alakult ki a tekintetben, hogy a pszichológiai folyóiratokban megjelent eredmények mennyire hitelesek (Pashler és Wagenmakers, 2012). A feltárt problémák elsôsorban a szociálpszichológiát érintették, de kiterjedtek más tudományterületekre is (pl. idegtudomány: Lisberger, 2013; orvostudomány: Bozzo, Bali, Evaniew és Ghert, 2017). A feltárt súlyos zavarok a Brian Nosek nevével fémjelzett Megismétlési Projekthez (Open Science Collaboration, 2015) vezettek, amely megerôsítette a válságérzetet, mivel alacsony közvetlen megismételhetôségi arányt mutatott ki (ismét csak nem egyedülálló módon a pszichológiában). A projekt eredményeinek értelmezése azonban összetett feladat, és az elmélyülő önvizsgálat a metodológiai 
tudatosság erôsödésének forrásává is vált. A 2010-es évek második felében reformmozgalom bontakozott ki a hibák kiküszöbölésére. Új ajánlások és új gyakorlatok születtek, ilyen például a publikációk elôregisztrációja (Nosek és Lindsay, 2018).

Tanulmányom célja ennek az összetett helyzetnek az áttekintése. Érinteni kívánom a válság okait, szimptómáit és tanulságait. Elsôként kitérek a megszaporodott csalások mibenlétére és hátterére, és az ennél jelentôsebb volumenú problémára: a vitatható kutatási eljárások elterjedésére. Ezt követôen kitérek a kiélezett verseny, az ösztönzési rendszer és a publikációs környezet hatásaira, és arra a jelenségre, hogy magas presztízsû folyóiratokban megkérdôjelezhetô minôségú kutatások jelenhettek meg. A 2010-es évek közepétôl nagy figyelmet kapott cikkek sorozata, majd a Megismétlési Projekt hívta fel a figyelmet a gondokra. Írásom második felében a problémák elemzésére és a következtetések levonására fókuszálok.

Mint ahogyan a problémák súlya sem egyaránt érinti a pszichológia különbözô területeit, úgy az önvizsgálatnak és a jobb kutatási gyakorlatok kialakulásának is területspecifikusnak kell lenniük. A válság egyben hosszú távú növekedési lehetôség, így a 2010-es évek metodológiai krízise is lehetôséget nyújt a fejlődésre, az önreflexión keresztül. Írásom abból a megfontolásból született, hogy bár a Megismétlési Projekt eredményeirôl széles körben lehetett értesülni, a válságjelenségek részletes és szisztematikus bemutatása, valamint az abból származó tanulságok összefogott áttekintése kevésbé elérhetô a szakirodalomban.

\section{TUDOMÁNYOS CSALÁSOK ÉS VITATHATÓ KUTATÁSI ELJÁRÁSOK}

A tudományos csalás hivatalos definíciójának és eljárási szabályzásának kidolgozása az 1990-es években kezdôdött el az Egyesült Államokban, elsôsorban a biomedikális kutatások területére koncentrálva (Lock, Wells és Farthing, 2001). A sok vita jelezte, hogy körültekintôen kell eljárni, mivel mind a csalások rejtve maradása, mind pedig az igaztalan vád jelentôs kárt okoz. A tudományos integritást felügyelô kormányhivatal (Office of Research Integrity) koordinálásával 1989-ben elfogadott definíció megállapítja, hogy a tudományos csalás megvalósulhat „kreált adatok előállításában, a felvett adatok megmásításában, plagizálásban vagy a megtévesztés más formáiban a kutatás pályázati, megvalósítási vagy publikálási fázisában” (Rennie és Gunsalus, 2001, 16). A szabályzás iránti igény jelezte, hogy akadémiai csalások korábban is elófordultak. A 2010-es években kiderített esetek viszont azt mutatták, hogy a hivatalos lépések nem voltak elégségesek a megelôzést illetôen.

A 2010-es években megrázó erejû volt a feltárt esetek mélysége és gyakorisága. Marc D. Hausert, a Harvard vezetô kutatóját (kutatási területe a kogníció és a moralitás evolúciója) az egyetem etikai bizottsága 3 éves belsô vizsgálat után, 2010-ben találta bûnösnek adathamisítás miatt (Newcomer és Spitzer, 2010). Hauser és másik két munkatársa egyik jelentôs publikációját (Hauser, Weiss és Marcus, 2002) visszavonták, de ezt a tanulmányt (amelyre azóta az adatbázisok „retracted” jelzóvel adnak ki találatot) addigra már 151 esetben idézték. 2011-ben Diederik Stapel, egy holland egyetem elismert szociálpszichológus kutatója ellen indult vizsgálat (kutatási területe a hatalommal és a sztereotipizálással kapcsolatos szociális viselkedés), amely több éven 
át tartó adatmanipulációt és kreált adatok használatát állapította meg. A Retraction Watch internetes oldal Stapel esetében 58 visszavonásról számol be 2017 októberében (Palus, 2015). Stapel elismerte a csalást, és egy könyvben megírta saját történetét (Stapel, 2014).

További esetekre is fény derült, vezetô kutatók érintettségével: Karen Ruggiero, Harvard University, 2 visszavont cikk szociális igazságosság témában; Dirk Smeester, Erasmus University Rotterdam, 7 visszavont cikk szociális priming témában; Lawrence Sanna, University of Michigan, 8 visszavont cikk különbözô szociálpszichológiai témákban. A leleplezések tovább folytatódtak (Van Kolfschooten, 2014; O’Grady, 2017). 2017-ben Brian Wansink, a Cornell Egyetem vezetô táplálkozáspszichológusa körül alakult ki botrányos helyzet. Wansink három évtizedes tevékenysége alatt több száz tanulmányt publikált, több mint húszezres idézettséget ért el, több könyve bestseller lett. Emellett az amerikai kormány tanácsadója volt, és „Smarter Lunchrooms” nevú kezdeményezése keretében több ezer iskolai menzán az ő kutatásai alapján futtatnak egészséges táplálkozás programokat. A problémákra 2017-ben derült fény, számos cikkét rohamos gyorsasággal vonták vissza (van der Zee, 2017). Ezek a neves szerzők sok kollégával együttmúködésben dolgoztak, így a társszerzók és a kezük alá dolgozó doktori diákok szélesebb körének szakmai integritása és jövője is kérdésessé vált.

Az akadémiai csalások terén korántsem a pszichológiára korlátozódó problémáról van szó. 2011-ben például a UCLA egyik politikatudomány szakos PhD hallgatója hamisított adatokat egy érdekes eredmény megkonstruálása érdekében, és a kutatást egy neves professzorral együtt közölte le, aki csak a nevét adta a kutatáshoz (Singal, 2015). Ugyanebben az évben a Boston University egyik rákkutató professzora ellen merült fel megalapozottan a csalás vádja (Johnson, 2011). 2012-ben a biológiai területen derült ki, hogy szerzôk hamis néven saját cikkükrôl írtak lektori véleményt (Akst, 2012), majd 2017-ben a Tumor Biology c. folyóirat vont vissza 107 közleményt lektori vélemények meghamisítása miatt (McCook, 2017). A csalások mértékét tekintve tízszeres növekedést becsülnek meg egyes elemzések az 1970-es évekhez képest (Fang, Steen és Casadevall, 2012).

Hamarosan vizsgálódások indultak a pszichológia berkein belül annak felderítésére, hogy mennyiben beszélhetünk a jéghegy csúcsáról az említett esetekben. Egy kutatás 2009-ben becsülte meg korábbi felmérések metaelemzésére alapozva, hogy milyen gyakori lehet a tudományos csalás (Fanelli 2009). A kutatók 2 százaléka ismerte el saját magára nézve, anonim módon ezt a legsúlyosabb vétséget, viszont $14 \%$ állította, hogy személyes környezetében más kollégák elkövettek ilyent.

A vizsgálatok és elemzések (pl. Gadbury és Allison, 2012; Head, Holman, Lanfear, Kahn és Jennions, 2015; John, Loewenstein és Prelec, 2012; Fanelli, 2009, 2010) a csalások mellett egyéb, sokkal szélesebb kört érintố negatív jelenségekre is rávilágítottak. Ezek a kifogásolható, mégis gyakran előforduló eljárások az utóbbi idôben a „vitatható kutatási eljárások” („questionable research practices”) gyújtőnevet kapták (vö. Banks, Rogelberg, Woznyj, Landis és Rupp, 2016). Ilyen a szignifikancia manipulálása „rugalmas” adatkezeléssel (pl. a csoportszintû adatok összevonása vagy szétbontása), a statisztikai eljárások próbálgatása annak érdekében, hogy az eredmény elérje a szignifikanciaszintet („p hacking”); az elemzés megállítása egy kedvezó pontnál; a meghosszabbított adatgyújtés a jobb eredmény reményében, a post-hoc hipotézis állítás; a tendenciózusan szelektív adat- és eredményközlés; a kísérleti kondíciók és függố változók szelektív 
bemutatása; egy váratlan eredmény várt eredményként való beállítása; az eredmények felszabdalt publikálása a publikációk számának növelése érdekében; a minta korlátozottságát figyelmen kívül hagyó jogosulatlan általánosítás; a negatív eredmények nem közlése; és a nyers adatok rövid ideig történô tárolása.

Egy több mint kétezer fôs pszichológus kutató mintán végzett felmérés (John, Loewenstein és Prelec, 2012) megerôsítette a rossz praxisok elterjedtségét. A válaszadók több mint 50\%-a esetében elôfordult például, hogy az adatgyújtés során ellenórizte a szignifikanciaértéket és ehhez igazította a további adatgyújtést; több mint $60 \%$ szelektíven számolt be az alkalmazott függô változókról; és több mint 40\% ismerte el, hogy egyes adatokat azután zárt ki az elemzésból, hogy megnézte, a kizárás hogyan befolyásolja a szignifikanciaszintet. (A megkérdőjelezhetô eljárások elterjedtségét mutató további empirikus vizsgálatra lásd Banks és mtsai, 2016.)

A kutatók jó része nem tekinti súlyosnak ezeket a „szoft” módszertani vétségeket, amelyek pedig olyan tendenciózus rugalmasságot visznek a kutatási folyamatba, amely kipárnázza a kutatói hipotézist megerôsítô, pozitív eredményekhez vezetô utat. Ezek a szándékosan vagy átgondolatlan rutinból alkalmazott eljárások táptalajt jelentenek a kutatói elfogultság, és ezáltal a torzult eredményközlés érvényesülésének. Ennek eredménye az lehet, hogy a szakirodalomban elszaporodnak a hamis pozitív, azaz a kutatói hipotézist alaptalanul megerôsítettnek tekintô eredmények. Másként: gyakorivá válik a nullhipotézis helytelen visszautasítása - az a helyzet, amikor valósnak fogadunk el egy eredményt, pedig nem az (Simmons, Nelson és Simonsohn, 2011). Ha pedig egy-egy szakterületen megnövekszik a látens hamis pozitív eredmények jelenléte, amelyre újabb hamis pozitív eredmények épülhetnek, akkor hiába a produktivitás, nem bizonyos, hogy valóságos elôrelépés történik a kutatási területen.

A hamis pozitív eredmények problémája a 2010-es évek válságának középpontjába került. A további részletezés elôtt azonban vizsgáljuk meg, hogy milyen tényezók állhatnak az akadémiai csalások és rossz kutatási eljárások elterjedésének hátterében.

\section{AZ ÖSZTÖNZÉS, A VERSENY ÉS A PUBLIKÁCIÓS KÖRNYEZET}

Kérdés, hogy miért követnek el jól képzett kutatók módszertani vétségeket, és egyesek miért mennek el az adathamisításig? A kutatók számának exponenciális növekedése (Bornmann és Mutz, 2015) bizonyosan magával hozza a negatív jelenségek megnövekedését is. Az egyéni felelôsség megkérdôjelezhetetlen, de ha nem elszórtan és periférikusan jelentkeznek a problémás jelenségek, akkor el kell gondolkodni azon, hogy vannak-e olyan rendszerszintû háttértényezók, amelyek nemkívánatos módon befolyásolják a kutatók gyakorlatát.

Indokoltnak tûnik a fô tényezôcsoportot a felerôsödött versenyben és publikációs nyomásban látni (Editors, 2011). ${ }^{1}$ A verseny mindig részét képezte a tudomány múkö-

Ennek a kérdéskörnek igen nagy a szakirodalma. Szelektíven a következố referenciákat lehet említeni: Anderson és mtsai, 2007; Miller, Taylor és Bedeian, 2011; Sarewitz, 2016; Waaijer, Teelken, Wouters és van der Weijden, 2017. Hazai vonatkozásban: Csaba, Szentes és Zalai, 2014; Marton, Varró és Varró, 2004; Papp, 2004; Tóth, 2014. 
désének. Az állásokért, pozíciókért és kutatási erôforrásokért folytatott jelenlegi kompetíció kiélezettebb, mint korábban volt. Versenyben állnak egymással az egyes kutatók (az állásokért és a karrierben való elômenetelért), a kutatócsoportok (a pályázati pénzekért), az egyetemek (a diákok megszerzéséért) és a folyóiratok (az olvasók és a finanszírozás megszerzéséért). A versenymezóny tipikusan magas színvonalú. A kiválóak a még kiválóbbakkal állnak versenyben, gyakran az is erôs teljesítményt mutat fel, aki veszít, de vannak, akik még jobbak. A 21. század elején mindez egy folyamatos, élesedó egzisztenciális és pszichés „karriernyomás” részeként jelenik meg az akadémiai életben. Erik Poehlman, a University of Vermont kutatója, aki 12 hónapot töltött szövetségi börtönben adathamisításért, tettét részben annak tudta be, hogy úgy látta, pozícióját és önértékelését csak a folyamatos sikerrel tudja fenntartani (Interlandi, 2006).

Miközben a versenynek ismert a hatékonyságnövelô hatása, az is tudott, hogy a túl erôs versengés csökkenti a kreativitást és gátolhatja a kollektív előrehaladást (Fang és Casadevall, 2015). Anderson, Ronning, De Vries és Martinson (2007) 51 karrierjének közepén tartó kutatóval készített fókuszcsoport-interjút azzal kapcsolatban, hogy hogyan élik meg a folyamatos versenyhelyzetet. A következó negatív tendenciák rajzolódtak ki: 1. a saját eredmény felnagyítása mások odavágó munkájának elhallgatásával, 2. adatvisszatartás a saját pozíció erôsítése céljából; 3. a lektorálás felhasználása manipulatív célokra; 4. rossz kutatási gyakorlatok alkalmazása a pozitív eredmény és a publikálhatóság érdekében.

A tudományos teljesítmény folyamatos mérésére alapuló ösztönzési rendszer, a „publish or perish” normatíva a gyorsan és biztosan publikálható eredmények felé tereli a kutatókat, és ez szerepet játszik a csalások és problémás eljárások elszaporodásában. A publikációs nyomással más jelenségek is összefüggésbe hozhatóak, így például az egy cikkre esố szerzőszám növekedésének jelensége, ami egyrészt a teammunka szükségszerü következménye, de nehezen mérhetô mértékben a „szívességi” vagy „stratégiai” szerzôség elszaporodását is jelzi. Továbbá ide sorolható az eredmények többszörös vagy felszabdalt publikálása, amely elvezetett a „legkisebb publikálható egység” fogalmának megjelenéséhez (Wesel, 2016; Biswanger, 2014).

Az utóbbi idôben a publikációk számának növelésével szemben elôtérbe került a magas impaktfaktorú folyóiratokban való közlés fontossága (Franco, 2013). Lényeges megnézni, hogy mi jellemzi az ezen folyóiratok által kialakított publikációs környezetet, mert ez a kutatási gyakorlat fontos szabályzó eleme. Két tényezô emelhetô ki ebben az összefüggésben: 1. a folyóiratok nem publikálnak negatív eredményeket; 2. a folyóiratok szerkesztôii elôtérbe helyezik az újdonságértékú, érdekes, meglepó eredménnyel rendelkezô kutatásokat (Fanelli, 2012; Head, Holman, Lanfear, Kahn és Jennions, 2015). E trendek mögött a szakmai és médiafigyelem megragadására rányuló verseny húzódik meg. A kutatók tehát különösen érdekeltek az újdonságértékú, meglepô és érdekes („szexi”) eredmények termelésében.

Természetesnek tûnhet a negatív vagy kevésbé újszerú eredményekkel szembeni érdektelenség. A negatív eredmények „fiókban maradása” (Rosenthal, 1979), csakúgy, mint a kutatói elfogultság a saját hipotézissel / elmélettel szemben, igencsak régi probléma (Sterling, 1959; Sterling, Rosenbaum és Weinkam, 1995). A probléma súlya és következményei iránti érzéketlenség azonban újra elôtérbe került a 2010-es évek vitáiban. A negatív eredmények nem közlése összetett kérdés. Óhatatlan, hogy a tu- 
dományos közlemények többsége pozitív eredményeket közöl. Világos azonban, hogy torzulásokhoz vezet, ha szélsôségesen érvényesül ez a tendencia. A negatív eredmények a tudományos kutatás szerves részét képezik, információs és falszifikációs értékük jelentôs. Ha egy-egy kutatási terület fejlôdésébe csak a pozitív eredmények épülnek be, akkor ez gyengíti az eredmények robusztusságának megítélhetôségét. A kutatás szintjén a negatív eredménnyel szembeni averzió a mindenáron való szignifikáns eredmény imperatívuszát hozza magával, a szakterület szintjén pedig a „publikációs torzulást” („publication bias”): a pozitív eredmények aránytalan túlsúlyát. Számszerú elemzések is alátámasztják, hogy a negatív eredmények gyakorlatilag hiányoznak a pszichológiai szakirodalomból; bár a tendencia más tudományágakban is jelen van, a pszichológia élen jár ezen a téren (Fanelli, 2010, 2011; Pautasso, 2010).

A pszichológiai szakirodalomban régóta erôs a pozitív eredmények közlésének túlsúlya (vö. Sterling, 1959; Sterling, Rosenbaum és Weinkam, 1995). Fanelli (2010) több mint kétezer publikációt átfogó elemzése szerint ez jelenleg a pszichológiában és pszichiátriában 95,1\%, miközben az idegtudományokban 85\%, és a legtöbb negatív eredményt közlô úrtudományban 70,2\%. Ezzel az eredménnyel a pszichológia és a pszichiátria az elsố helyet foglalja el a pozitív eredmények szakirodalmi arányát tekintve a vizsgált 20 tudományág között.

A publikációs nyomás erôsödésével a kutatók ellentmondásos helyzetbe kerültek: a tudományos kutatás természeténél fogva bizonytalan kimenetelú vállalkozás, ami kockázattal jár: a hipotézisek egy része (jó esetben) bukásra van ítélve. Ennek a ténynek az elismerését azonban az ösztönzési és közlési rendszer nem tükrözi. A 2010-es évek önvizsgálata (amelynek részleteire a továbbiakban kitérek) azt mutatja, hogy a makrorendszer a nemkívánatos eljárások felé terel sok kutatót, és olyan lokális szubkultúrák alakulhatnak ki, amelyben sok minden megengedett a publikálható cikkek megírása érdekében.

A problémákat emellett az is jelezte, hogy alapvetô kétségeket ébresztő publikációk jelenhettek meg vezetô folyóiratokban.

\section{DARYL BEM 2011-ES PARAPSZICHOLÓGIAI PUBLIKÁCIÓJA}

A pszichológia területén Daryl Bem parapszichológiai témájú cikke váltott ki katalizáló hatású sokkot. A cikk az APA által kiadott Journal of Personality and Social Psychology-ban jelent meg (Bem, 2011). Bem cikke a jövőbe látás („prekogníció”) extraszenzoriális jelenségét vizsgálta kísérleti módszerrel, a Cornell University több mint ezer BA diákja részvételével. Bem 9 kísérletet közölt, amelyek közül 8 gyenge, de statisztikailag szignifikáns eredményt talált amellett, hogy bárki rendelkezik valamilyen szinten a prekogníció intuitív képességével.

Az egyik kísérletben a vizsgálati személy két függönyt látott a képernyőn, és el kellett találnia, hogy melyik mögött van eltakart kép. Eltakart kép azonban a válaszadáskor még nem volt egyik függöny mögött sem, csak a válaszadás után dólt el automatizált random módszerrel, hogy melyik mögé kerül kép. A vizsgálat logikája szerint, ha konzisztens módon magasabb a találati arány a véletlennél, akkor ez a prekogníció bizonyítékaként értékelhetô. További kísérletekben a résztvevốk azokra a szavakra jobban 
emlékeztek, amelyeket csak a kísérlet egy további fázisában kellett leírniuk; félelmi reakciót mutattak félelemkeltô inger bemutatását megelôzôen; és habituálódtak olyan kellemetlen ingerekre, amelyeket csak a habituáció után kaptak meg (Bem, 2011).

A publikáció közlése (amelyet erôs médiafigyelem követett) a parapszichológia meghatározó pillanata volt, mivel példa nélkül állt egy ilyen témájú tanulmány megjelenése vezetố tudományos pszichológiai folyóiratban. Mások számára viszont zavarba ejtô volt, hogy a lektorok (a szerkesztôség négy lektort kért fel a szokásos kettô helyett) nem találtak kifogásolnivalót sem a módszertanban, sem a statisztikában. Ez egy olyan helyzethez vezetett, hogy vagy a tudományos józan észt és az ismert fizikai törvények érvényességét kellett az olvasónak felfüggesztenie, vagy az abba vetett hitet, hogy a pszichológia konvencionális játékszabályai megfelelően múködnek.

A megjelenés után többen kritikai vizsgálat alá vetették Bem kutatásait. Bem nyitottan, sốt, ösztönzóen állt a rigorózus ellenôrzések elé - számolt ezzel, amikor a publikáció megjelentetésére készült. Módszertani problémákat a vizsgálódások valóban feltártak: így például előfordult, hogy a kísérleti protokollt menet közben megváltoztatták, a statisztikai feldolgozás során különböző adatcsoportokat ad hoc módon vontak össze, és nem lehetett tudni, hogy hány személy adata maradt ki a végsô elemzésbôl (Alcock, 2003). Ezeknek a nem túl jelentôs elemzési döntéseknek a feltárása (amelyeket maga Bem is elismert) azonban nem volt perdöntô, mivel lényegében minden, amit Bem csinált, bevett gyakorlat volt a pszichológiai kutatásban. Sôt, Bem sok tekintetben az átlagosnál is körültekintôbben járt el a publikált kísérletek során (LeBel és Peters, 2011).

Alcock (2003) meglátása szerint alapvetô probléma, hogy a parapszichológusok valójában nem adnak esélyt a nullhipotézisnek; annyira hisznek a vizsgált psi jelenség létezésében, hogy tudatosan vagy tudattalanul az eredményesség irányába terelik a vizsgálat folyamatát, ha pedig nem jön ki pozitív eredmény, akkor vagy addig keresgélnek, amíg az ki nem jön, vagy pedig hajlékonyan, egyéb lehetséges okkal magyarázzák a sikertelenséget. 2012-ben a Journal of Personality and Social Psychology leközölt egy kutatást, amelyik megismételte Bem kísérleteit, de nem mutatott ki prekogníciót (Galak, LeBoeuf, Nelson és Simmons, 2012; a kutatást elózetesen több folyóirat visszautasította arra hivatkozva, hogy negatív eredményt nem közölnek, vö. Yong, 2012a). Más megismétlések is negatív eredménnyel zárultak, a vizsgált psi jelenségekbe vetett pro és kontra hitek azonban zavartalanul fennmaradtak.

A Bem-cikk egyféle lakmuszpapír volt: fókuszált sokakban már jó ideje meglevố aggodalmakat. A gondok túlmutattak a parapszichológián; fontosabbnak mutatkoztak a tudományos pszichológia múvelését érintô következtetések. Bem cikke azért volt jó kiindulópont az általánosabb tanulságokhoz, mert az abszurd eredményhez a bevett módszertan alapján jutott. Carl Sagan népszerúsítette azt a tudomány klasszikusai által megfogalmazott szabályt, miszerint rendkívüli állításokat rendkívül erôs bizonyítékokkal kell alátámasztani. A Bem-féle kutatás ennek a követelménynek nem felelt meg, de az elfogadott tudományosság játékszabályai szerint játszott. Az aggasztó felismerés az volt, hogy a hibákat és torzításokat, amiket a rendszer nem szúrt ki, tulajdonképpen bárki elkövetheti. 


\section{TOVÁBBI KÉRDÉSES CIKKEK VEZETÔ FOLYÓIRATOKBAN}

A 2010-es évek elején világossá vált, hogy kérdéses minôségú cikkek jelenhettek meg jó nevú tudományos folyóiratokban. Három szociálpszichológus: Uri Simonsohn, Joseph Simmons és Leif Nelson listázni kezdték azokat a tanulmányokat, amelyek hiteltelennek tû́ntek (Simmons, Nelson és Simonsohn, 2018; Shea, 2012). Az egyik ilyen publikáció Lawrence Sanna és munkatársainak a vizsgálata volt (Sanna, Chang, Miceli és Lundberg, 2011), amelyik a Journal of Experimental Social Psychology-ban jelent meg. A szerzők azt a hipotézist ellenőrizték egy kísérletsorozattal, hogy az emberek proszociálisabban viselkednek fizikailag magasabban levô pozícióban. Az eredmények igazolták az elvárásokat: azok, akik egy mozgólépcsôn felfelé utaztak, többet adományoztak, mint azok, akik lefelé utaztak, és hosszabb ideig segítettek másoknak azok, akik magasabban ültek. A kritikai átvilágítás statisztikai hibákat mutatott ki, és adatmanipulációt is vélelmezett. Késôbb az elsố szerzô cikkét (több más cikkével együtt) visszavonták (Yong, 2012b).

Sanna és munkatársai ahhoz a paradigmához kapcsolódtak, amely a Yale Egyetemen John Bargh munkájából nőtt ki. A „szociális priming” elnevezésú kutatási terület olyan vizsgálatokat foglal magában, amelyek a finom fizikai ingerekkel történô elôfeszítés tudattalan viselkedésmódosító hatását igyekeznek kimutatni. Az elsố, sokat idézetté vált kutatásban (Bargh, Chen és Burrows, 1996) Barghék öregséggel kapcsolatos hívószavaknak tették ki a kísérletben résztvevóket, és azt találták, hogy az elơfeszítést követôen a vizsgálati személyek lassabb ütemben hagyták el a vizsgálat helyszínét, mint azok, akik nem voltak kitéve ennek az elôfeszítésnek. Miközben felkapottá vált a kutatási terület, kétségek merültek fel az eredmények megbízhatóságával kapcsolatosan. Néhányan közvetlen megismétlést kezdeményeztek, és ezek rendre negatív eredménynyel zárultak. 2012-ben Stephane Doyennek és munkatársainak sikerült a negatív eredményeket és a kutatásokkal kapcsolatos kételyeiket publikálniuk (Doyen, Klein, Pichon és Cleeremans, 2012). Még ebben az évben a Nobel-díjas pszichológus közgazdász Daniel Kahneman a Nature-ben nyilvános emailben kérte a terület kutatóit, hogy a különbözố laborok független replikációval igyekezzenek mielőbb tisztázni a szociális priming hatások valódiságát a kutatási terület hitelességének megốrzése, valamint a területen dolgozó fiatal kutatók jövôje érdekében (vö. Yong, 2012c.; Kahnemann 2011-ben megjelent „Thinking fast and slow” címú könyvében maga is épített a szóban forgó kutatásokra, így könyvét is érintették a kérdésesnek mutatkozó eredmények).

A kételyeket keltô publikációk közé sorolható a Harvard Business School szociálpszichológusának, Amy Cuddy-nak a kutatása is, amely a Psychological Science címú folyóiratban jelent meg (Carney, Cuddy és Yap, 2010). A kísérleti kutatás a „hatalmi póz” (egyfajta kiterjesztett testtartás) hatását vizsgálta, és megerősítette azt a feltételezést, hogy a testtartás 1 perces gyakorlása azonnali pozitív fiziológiai és viselkedéses változásokat eredményez: a kísérleti csoportban levốk tesztoszteronszintje megemelkedett, kortizolszintje csökkent, kompetenciaérzésük és rizikóvállalásuk megemelkedett a kontrollcsoporthoz képest, akik 1 percet összegörnyedt testtartásban töltöttek. A kutatás módszertanát késôbb komoly kritika érte (Simmons és Simonsohn, 2015; Gelman és Fung, 2016). 2016-ban a szenior szerzôtárs, Carney elhatárolta magát a kutatástól: azt nyilatkozta, hogy nem hiszi, hogy a hatalmi póz hatása valós (Singal, 2016). 
További példa lehet a Kristina Durante nevével fémjelzett vizsgálat (Durante, Rae és Griskevicius, 2013), amely a nôk politikai szavazással kapcsolatos magatartását vizsgálta a 2012-es elnökválasztási kampányt követôen; a publikáció szintén a Psychological Science c. folyóiratban jelent meg. Az evolúciós pszichológiával elkötelezett kutatás feltevései szerint ovulációs idôszakban a nôk nyitottá válnak a rövid távú szexuális kapcsolatokra, és olyan férfiakat preferálnak, akik a genetikai fitnesz jegyeit hordozzák - ilyen az attraktivitás és az arcszimmetria. Mivel ezekkel a jegyekkel Obama inkább rendelkezik, mint Romney, várható, hogy az ovuláló nók inkább Obamára szavaznak. Feltételezték továbbá, hogy mivel a rövid távú szexuális kapcsolatok nem illeszkednek a vallásossághoz, „az ovuláció liberálisabbá, egyben kevéssé vallásossá teheti a nôket” (i. m. 2.). A megjelenés utáni kritika az elméleti háttér spekulatív jellege mellett komoly módszertani-statisztikai problémákra mutatott rá (Gelman, 2013).

Melyek a közös vonásai az említett (és más hasonló) cikkeknek? 1. Érdekes és meglepô eredménnyel állnak elő; 2. Elméleti hátterük gyenge; 3. Kis mintán végzett néhány kísérletre alapoznak, majd túlzó és kétséges konklúziókat vonnak le gyenge bizonyítékok alapján; 4 . Anonim szakmai bírálattal dolgozó vezetô folyóiratokban jelennek meg, amelyek igen magas visszautasítási rátával múködnek, így feltételezhetốen csak a legjobb minôségú kutatásokat publikálják; 5. A publikálás után komoly problémákra derül fény.

Önmagában nem meglepô, hogy előfordulnak gyenge minôségú vagy kétes eredményú kutatások és óvatlan lektorok. A tudományterület diszfunkcionális múködését mutatja viszont, ha a kétséges minôségú tudomány a szakmai szúrôkön átjutott legjobb tudományként kerül elénk. Növeli a problémát, ha erre a tudományos kommunikáció torzulásai is rárakódnak.

\section{TORZULÁSOK A TUDOMÁNYOS KOMMUNIKÁCIÓBAN}

A tudományos tömegtermelés és a tömeges tudományos hírfogyasztás idôszakában éles verseny bontakozott ki a médiafigyelem megragadása érdekében. A tudományt nemcsak mûvelni kell, de el is kell tudni adni. Az „eladás” a kutatók és a kutatás mögött álló intézmények számára a médiafigyelem megragadásának feladatát jelenti. Mindez korunk természetes velejárója, azonban érzékelhetô a „média impaktfaktor” negatív hatása. Ezek közül szembetûnố megnyilvánulás az ún. „overselling”: az eladásra irányuló túlzó igyekezet.

Tanulságos történet Amy Cuddy-é, akinek hatalmi pózzal kapcsolatos kutatásairól már volt szó. Cuddy a Psychological Science-ben megjelent, szerzôtársakkal írt cikke (Carney, Cuddy és Yap, 2010) nyomán vált széles körben ismertté. Az érdekes kutatási eredményt a média hamar felkapta, és ennek eredménye lett 2012-ben a TED történetének második legsikeresebb előadása, amit 2017-ig több mint 43 millió ember nézett meg. Amy Cuddy kiváló előadói képességének és inspiratív beszédének köszönhette a sikert, aminek fơ hitelességét mégis legfőképpen a Harvard Egyetem keretében végzett tudományos kutatás, és az a felszított remény adta, hogy bárki néhányszori pár perces hatalmi póz gyakorlással jelentôsen javítani tudja esélyeit, hogy nehéz helyzetekben helytálljon, sốt megváltoztassa az életét. Sikerkönyvében Cuddy 
(2015) már azt is kijelentette, hogy a hatalmi póz gyakorlása eszköz lehet a nôk és a kisebbségi csoportok helyzetének javítására. 2017-re azonban már egy tucat megismétlést végeztek, amelyek nem erôsítették meg az eredeti kutatási eredményeket. Cuddy a kritika kereszttüzébe került, és 2017-ben elhagyta a Harvardot (vö. Engber, 2017, Dominus, 2017).

A klasszikus munkamegosztás szerint a jó minôségú, érvényes és megbízható kutatás végzése a tudományos kutatók dolga, a tudományos szúrôn átment publikálás a folyóiratoké, a fontos eredmények széleskörú közzététele pedig a hírügyökségeké és a médiáé. A rangsorolásért, finanszírozásért és hallgatókért folytatott versenyben azonban ez a modell módosult: a kutató egyetemek PR, illetve sajtórészlegeket hoztak létre, és gyakorlattá vált, hogy az egyetemen folyó kutatásokról a saját ügynökség tájékoztatja a médiát. Az egyetem vezetésének elvárása, hogy az intézményben folyó kutatások a lehetô leggyorsabban, a lehetô legszélesebb körben kapjanak nyilvánosságot. Ismert panasz, hogy a média torzítja a tudományos híreket. A mai helyzetben úgy tûnik viszont, hogy a felelôsségben osztoznak a kutatógyetemek PR-sajtó részlegei, és maguk a kutatók is (vö. Moore, 2006).

Rossz gyakorlatként kialakult az a szokás, hogy a tipikusan kis mintán végzett, elsô eredményeket hozó kutatásokat megbízható, áttörô eredményként mutatják be a sajtónak, még mielôtt a publikáció megjelenne szakmai bírálatot alkalmazó folyóiratban (vö. Brown, 2012; Brechman, Lee és Cappella, 2011). A torzító túlzások már az egyetemek közleményeiben megjelennek, pedig a sajtóosztályok átalában jóváhagyatják a közleményeket magukkal a kutatókkal is. Íme egy példa a szenzációhajhász egyetemi sajtóközleményekre: A Hibbing, Smith és Alford (2014) „Predisposed: liberals, conservatives and the biology of political differences" c. publikációját bemutató közlemény így zárul: „A politika feltehetöen nem a lelkünkben van, hanem a DNS-ünkben - állítja John Hibbing és Kevin Smith (UNL) és John Alford (Rice University)" (Office of University Communications, University of Nebraska-Lincoln, jul. 31, 2014).

\section{SZEMBENÉZÉS A PROBLÉMÁKKAL}

2005-ben John Ioannidis epidemiológus (Stanford University) megjelentetett egy cikket a PLoS Medicine folyóiratban, a következô provokatív címmel: „Why most research findings are false" (Ioannidis, 2005). A cikk megállapítja, hogy az orvostudományban erôsödố aggodalom van a tekintetben, hogy a publikált kutatási eredmények többsége nem valós. Ioannidis nem szándékos hamisításról beszélt, hanem arról, hogy az általa jól ismert kutatási gyakorlat hiányosságai, együttjárva az elterjedt statisztikai elemzések tárházával, hamis eredményekhez vezethetnek még jóhiszemú eljárás mellett is. A bajok forrásaként olyan jellemzôket említett meg, amelyek hosszú évek alatt beépültek a kutatási gyakorlatba és elnézettekké váltak; ilyen a kis mintán végzett adatgyújtés, az alacsony hatásnagyság elfogadása, a statisztikai programok, amelyek sokféle elemzési lehetôséget kínálnak fel, de a felhasználó nem teljesen érti ezeket. Mindehhez hozzájárul a mindenáron való publikálás motivációja. Ioannidis azt a lehetôséget vetette fel, hogy a megalapozatlan kutatási eredmény az orvostudományi közleményekben nem ritka anomália, hanem tömeges jelenség. 
Volt aki vitatta, volt aki megerôsítette a drámai felvetést, a cikk mindenesetre nagy figyelmet váltott ki, és egy megismétlési hullámot indított el. Ennek során az Amgen Inc. gyógyszergyártó cég független megismétlést végeztetett a rákkutatás területén mérföldkônek tekintett, a Nature-ben megjelent eredményekre vonatkozóan. Ennek keretében 53-ból 47 esetben nem sikerült az eredményt reprodukálni (Begley és Ellis, 2012). A Bayer által indított hasonló projekt, amelyik kísérleti stádiumú gyógyszerekre vonatkozó publikált eredményeket ismételtetett meg, 65\%-os eredménytelenséget hozott (Mullard, 2011). A rákkutatás területén azóta is több megismétlési projektet végeznek, és a terület komolyan keresi a rossz gyakorlatoktól való megszabadulás módját (vö. Errington, Iorns, Gunn, Tan, Lomax és Nosek, 2014).

2008-ban egy hasonlóan erôs nyelvezettel megfogalmazott cikk jelent meg a szociális idegtudományi vizsgálatokban elterjedt kétséges elemzési eljárásokról, amely lehetetlenül magas korrelációs értékek közlésében nyilvánult meg (Vul, Harris, Winkielman és Pashler, 2009; A cikk eredetileg a „Voodoo correlations in social neuroscience” címet viselte, amit késóbb a szerzôk szerkesztôi kérésre „Puzzlingly high correlations in fMRI studies of emotion, personality, and social cognition" címre változtattak). Vulék sok vizsgálat alapján arra figyelmeztettek, hogy az fMRI-vizsgálatokban a valamilyen szociális válasz és egyes agyterületek aktivitása közötti korrelációs értékek irreálisan magasak, és ezért túlbecsültek. Legfóképpen azért, mert a kutatók szelektíven azokat a mérési pontokat (voxeleket) választják ki a lehetséges választékból, amelyek maximális korrelációt mutatnak. Egy másik elemzés arra mutatott rá, hogy „voodoo” korrelációk nemcsak az idegtudományok terén bukkannak föl (Fiedler, 2011).

Meghatározó publikációk a pszichológia vonatkozásában is születtek, és nagyban hozzájárultak ahhoz, hogy a tudományterület szembenézzen a kialakult rossz eljárásokkal.

2011-ben (két hónappal a Bem-cikk megjelenése után) Joseph Simmons, Leif Nelson és Uri Simonsohn közöltek egy pszichológiai kutatásokat célba vevô cikket: „False-positive psychology: Undisclosed flexibility in data collection and analysis allows presenting anything as significant” címmel (Simmons, Nelson és Simonsohn, 2011). A szerzók egy képtelen kérdésre épített szimulációs kísérlettel illusztrálták mondanivalójukat. A kísérleti feltételben virtuális egyetemi hallgatók a Beatles „When I'm Sixty-Four” címú számát hallgatták meg, míg a kontrollcsoport másik zenét hallgatott. A szignifikáns eredmény igazolta az abszurd hipotézist: a szám meghallgatása több évvel fiatalabbá tette a vizsgálati személyeket. Az adatokat megszokott eljárásokkal, menet közben ad hoc elemzési döntéseket hozva dolgozták fel. A konklúzió: bármilyen értelmetlen hipotézis könnyen kihozható szignifikáns eredményre a bevett rugalmas gyakorlatnak megfelelố adatelemzéssel.

A cikk fố állítása az volt, hogy bár a pszichológiai kutatások névlegesen a $\leq .05$ szignifikanciaértéket teljesítik, azaz .05 szinten rögzítik a „hamis pozitív” következtetések valószínúségét, valójában jóval gyakoribb a hamis pozitív eredmények elôfordulása. Ez elsôsorban az adatgyújtés és adatelemzés során helytelenül megengedett ad-hoc döntéseknek köszönhetô, amelyek segítségével lényegében bármely hipotézis igazolható. A szerzôk véleménye szerint a rossz eljárások elterjedtségének következtében akár 60\%-ra is felmehet a hamis pozitív eredmények aránya és ezáltal a publikációs torzulás 
egy-egy terület szakirodalmában. Ioannidishez (2005) hasonlóan tanulmányuk arra figyelmeztetett, hogy a publikált szakirodalomban messze magasabb lehet a hamis pozitív eredmények aránya, mint bárki is gondolta.

Végül említeni kell Andrew Gelman és Eric Loken 2013-as meghatározóvá vált cikkét (Gelman és Loken, 2013), amely pontos elemzéssel tovább tudatosította, hogy a kutatók akkor is belevihetnek torzítást az adatelemzésbe, ha nem szándékoznak ismert nemkívánatos eljárásokba (pl. p hacking) bocsátkozni.

\section{A MEGISMÉTLÉSI PROJEKT ÉS AZ ÖNIZSGÁLAT}

A fent leírt előzmények összefüggésében érthetô, hogy 2011-ben Brian Nosek, a University of Virginia szociálpszichológusa miért indított másokkal együtt kezdeményezést egy, a pszichológiát érintő kiterjedt megismétlési projekt érdekében. A kezdeményezés egyben a Center for Open Science létrehozását is eredményezte, melynek célja az, hogy bármely területen elôsegítse a tudományos tevékenység nyitottságát, integritását és reprodukálhatóságát (Open Science Collaboration, 2012).

A pszichológiára irányuló projekt 2011 novemberében indult, és az eredményeket 2015-ben publikálták (Open Science Collaboration, 2015). A „Reproducibility Project: Psychology” (a továbbiakban: Megismétlési Projekt) keretében 270 önkéntes közremúködô kutató vállalta, hogy elvégzi 100, 2008-ban megjelent vizsgálat pontos megismétlését. A publikációkat a Psychological Science, a Journal of Personality and Social Psychology és a Journal of Experimental Psychology: Learning and Memory címú vezetô folyóiratokból válogatták ki. Az eredeti szerzốk minden esetben együttmúködtek a vizsgálat apró részleteinek megosztásában. Az érdeklôdéssel övezett eredmények szerint csupán 36,1\% volt a sikeres megismétlések száma, ezekben az esetekben is azonban tipikusan kevésbé erôs eredményeket kaptak az ismétlésekben (Open Science Collaboration, 2015; Weir, 2015).

A sikertelen megismétlések nagy száma és a vezetô laborok érintettsége kétségtelenül rossz hír volt, és az sem nyújthatott vígaszt, hogy más tudományterületeken (így a már említett rákkutatásban és idegtudományban, de a közgazdaságtanban és a kémiában is) hasonló problémák ütötték fel a fejüket. Az értékelés azonban megfontolt értelmezést kíván. Elôször is felvethetô, hogy mit - vagy mit nem - bizonyít egy vizsgálat sikertelen megismétlése? Másrészt megválaszolandó kérdés, hogy mit jelent egy tudományterületre nézve a megismétlési kudarc magas aránya?

Hangsúlyozni kell, hogy a projekt nem azt mutatta ki, hogy a vizsgált kutatások 68,9 százaléka elvetendônek bizonyult, hanem azt, hogy ennyi esetben nem sikerült, pontos megismétlésre törekedve, az eredetihez közel hasonló eredményt reprodukálni egyetlen független megismétlés alkalmával. Ugyanakkor a pontos közvetlen megismételhetôség a tudományosság egyik alapkritériuma. Nem véletlenül jelentette ki Karl Popper, hogy „a nem megismételhetô egyszeri eredményeknek nincs tudományos jelentôségük” (Popper, 1959, 66). Ha a fizikában egy kutatócsoport közvetlen bizonyítékot talál a gravitációs hullámok létezésére Einstein száz évvel korábbi hipotézisét megerôsítve, de azt más kutatócsoportok nem tudják megerôsíteni, akkor kétségessé válik a gravitációs hullámok létezésébe vetett hitünk, még ha Einstein hipotézisérôl van is szó. 
Másrészt viszont: mi van akkor, ha az ismétlôk tévednek, vagy ôk az elfogultak? Egyetlen vizsgálatot sem lehet teljesen pontosan megismételni. Mi van akkor, ha az ismétlés megváltoztatja a feltételeket, és ezek az akár csak kismértékú eltérések az okai annak, hogy más eredmény jön ki? És mi van akkor, ha idôközben megváltozott maga a jelenség? Többféle oka lehet a pontos megismétlés kudarcának. Felmerül a konceptuális megismétlés kérdése is, amely arra utal, hogy hogyan értelmezhetô az a helyzet, amikor egy vizsgálatot más kutatások kisebb-nagyobb változtatásokkal ismételnek meg, ugyanarra a fớ hipotézisre építve. Mennyiben tekinthetố egy ilyen megismétlés pozitív eredménye az eredeti vizsgálat megerôsítésének? Továbbá: mi a megismételhetôség elvárható aránya? 100\% bizonyosan nem, hiszen még a legjobb minôségú tudományban is jelen van a bizonytalansági faktor. Ezek jogos kérdések és felvetések, a válaszok keresését azonban folytassuk azzal, hogy megvizsgáljuk, milyen meglátásokat kínált fel a problémák hátterét kutató kollektív gondolkodás.

\section{A pontos megismétlések hiánya a pszichológiai szakirodalomban}

A pontos megismétlések hiánya a szakirodalmat ismerve bárkinek feltúnhet. Makel és munkatársai viszont szisztematikusan megvizsgálták 100 tudományos pszichológiai folyóirat teljes publikációs történetét, és 1900-ig visszamenôleg megállapították, hogy a reprodukálás céljával végzett publikációk 1,07\%-ban fordultak elô a vizsgált anyagban (Makel, Plucker és Hegarty, 2012). Igen nagy ellentmondás van aközött, hogy a kutatásmódszertan „arany sztenderdnek” tekinti a közvetlen megismétlést (lásd a fenti Popper-idézetet, vagy pl. Jasny, Chin, Chong és Vignitery, 2011 állásfoglalását), a valóságban azonban senki sem múveli. A szakmai közösségekben a megismétlésnek alacsony a presztizse, sốt többnyire a kreativitás hiányának tekintik, ha valaki mások kutatási eredményeit kívánja megismételni. Mint láttuk, a folyóiratok megerôsítik ezt a hozzáállást azzal, hogy deklaráltan nem publikálnak megismétléseket (Makel, Plucker és Hegarty, 2012).

Van, aki szerint ez nem baj. Jason Mitchell szociálpszichológus (Harvard Egyetem) például kifejtette, hogy a megismétlésnek nincs értelme, mert 1. a sikertelen kísérleteknek nincs értelmezhetô tudományos jelentésük, ugyanis egy pszichológiai kísérletben mindig annyi rosszul kontrollált vagy kontrollálhatatlan ok játszik közre az eredményben, hogy sosincs kizárva, hogy ezek állnak a sikertelenség hátterében; 2. a megismétlést végzók sem tökéletesek, ôk is elkövethetik ugyanazokat vagy más hibákat, sốt elfogultak, mert eleve feltételezik, hogy az eredeti eredmény megbízhatatlan, így viszont a megismétlés sem lehet magasabb mérce (Mitchell, 2014). Mások (pl. Lutus, 2017) elfogadhatatlannak tartják ezt az érvelést. A megismétlésellenes hozzáállás szerint ha már valaki kimutatott egy új eredményt/hatást, még ha kis mintán és alacsony hatásnagysággal is, és az megjelent egy megfelelô impaktfatorral rendelkezố folyóiratban, akkor az megalapozott eredménynek tekinthetô. Ha viszont feladjuk a megismételhetôség kritériumát, akkor feladjuk a tudomány egyik alapkövetelményét. 


\section{Visszás gyakorlat a konceptuális ismétlések terén}

Ha közvetlen megismétlés nem is, de konceptuális megismétlés nagy számban található a pszichológiai kutatásokban és a szakirodalomban. Ezek lényege az, hogy a kutató egy kezdeti vizsgálatban teszteli a hipotézisét, és ha szignifikáns eredményt kap, akkor továbblép, hogy kicsit megváltoztatott feltételek mellett tesztelje a kérdést. Meggyózôek és jól publikálhatóak az olyan kísérletsorozatok, amelyek ilyen módon szolgálnak az eredeti hipotézis kiterjesztésére. Egyes érvelések szerint az ilyen konceptuális megismétlés értékesebb, mint a közvetlen megismétlés, mert egyszerre teszteli az eredeti eredmény validitását és kiterjeszthetôségét, és így megalapozottabbá teszi a konklúziót (az érvet kritikailag elemzi Pashler és Harris, 2012).

A konceptuális ismétlés jó kutatási stratégia, de a kialakult gyakorlat rejt magában problémákat. Ugyanis, ha a konceptuális ismétlés megerôsíti az eredeti eredményt, akkor ezt a kutató a hipotézis megerôsítésének tekintheti. Ha viszont a konceptuális ismétlés nem erôsíti meg az eredeti eredményt, akkor ritkán hajlik a kutató arra, hogy az eredeti hipotézisbe vetett hitét felülvizsgálja, mivel a módosított körülményeket és módszertant teheti felelôssé a kudarcért (vö. Meehl, 1967; Mitchell, 2014). Így a sikeres vizsgálat konceptuális megismétléssé válik, a sikertelen viszont módszertanilag hibás próbálkozásként végzi az ismeretlenség homályában. Amennyiben a konceptuális megismétlés az itt leírt gyakorlatnak megfelelôen történik, úgy gyenge bizonyíték, amely nem tekinthetô sem az eredeti eredmény megerôsítésének, sem érvényes kiterjesztésnek (vö. LeBel és Peters, 2011).

\section{A negatív eredmények mostoha státusza és a pubikációs torzulás}

Egy módszertanilag erôs bizonyítási rendszerben a negatív eredménynek tartalmi jelentése van: megkérdôjelezi a vizsgált hipotézis megalapozottságát. Ezzel összefüggésben beszélt Karl Popper arról, hogy egy elmélet csak akkor tekinthetô tudományosnak, ha cáfolható (Popper, 1959/2005). Tény azonban, hogy a negatív eredmény jelentése mindig sokértelmú, ezért a negatív eredmény nehezebben értelmezhetô, mint a pozitív. Továbbá, a tesztelt elméletbe/hipotézisbe vetett hit erôsségével arányos a hajlandóság arra, hogy a negatív eredményt módszertani problémákkal magyarázzuk (LeBel és Peters, 2011).

Nagyobb baj akkor keletkezik, ha egy terület kutatói kultúrájában bevett gyakorlattá válnak a hipotézis megmentésére tett manôverek, miközben a kutatók alig törekszenek komoly kihívás elé állítani elméleti feltevéseiket és megalapozatlannak nyilvánítani azokat, ha nem állják ki a tesztelés próbáját (Fanelli, 2010). Ebbe az irányba hat az a publikálási rendszer is, amely nem teszi lehetôvé a negatív eredmények közlését. Mindezek hatására a kutatói gyakorlatban elsikkad az eredmények idôt és erôforrást igénylő türelmes ellenôrzése, amelyben a megerôsítésnek (verifikációnak) és a megkérdőjelezésnek (falszifikációnak) egyaránt szerepe van.

Egyes megállapítások szerint a pszichológiai kutatás egész rendszerét áthatja a negatív eredmények iránti averzió. Ez viszont megteremti a „halhatatlan elméletek teme- 
tôjét" - a formálisan soha el nem utasított, de egy bizonyos futamidô után csendesen elhagyott elméletek és kutatási programok sorát (Ferguson és Heene, 2012, 555.; lásd még: Heene és Ferguson, 2017). A közvetlen megismétlés hiánya, a konceptuális megismétlések fent leírt rossz gyakorlata és a negatív eredmények mostoha helyzete oda vezet, hogy a szakirodalomba megkérdôjelezetlenül és tartósan beépülhetnek valótlan - tipikusan hamis pozitív - eredmények. Ezekre újabb megalapozatlan eredmények épülhetnek rá, és így akár egész kutatási területek virágozhatnak valódi megalapozottság nélkül (Pashler és Harris, 2012; LeBel és Peters, 2011; Fanelli, 2010).

\section{A mintanagysággal kapcsolatos problémák és a hamis pozitív eredmények}

Logikus feltételezés, hogy a Megismétlési Projektben mutatkozó nagyarányú megismételhetetlenség mögött részben a hamis pozitív eredmények állnak. Mint láttuk, ezek, és velük összefüggésben a megkérdőjelezhetô eljárások létére Simmons, Nelson és Simonsohn (2011), majd mások is (pl. Gelman és Loken, 2013; John, Loewenstein és Prelec, 2012) felhívták a figyelmet. A pontos megismétléssel és a negatív eredményekkel szembeni averzió, háttérben a mindig új, jól publikálható eredmények produkálására való késztetéssel, szintén egyértelmúen a hamis pozitív eredmények látens arányát növeli.

A hamis pozitív eredmény valószínúségét növeli az alacsony mintaszám és az ezzel járó alacsony statisztikai erô (Finkel, Eastwick és Reis, 2015). Egy 2011-es elemzés szerint a vizsgált APA folyóiratokban megjelent kutatások átlagos mintaszáma $\mathrm{N}=40$ volt, ami messze elmarad a kívánatostól (Marszalek, Barber, Kohlhart és Holmes, 2011). A statisztikai erô utólagosan kiszámítható a kísérleti feltételekre jutó vizsgálati személyek száma (cell size), a tipikus hatásnagyság (effect size) és a statisztikai szignifikancia köszöbértéke (alpha) alapján. Ezzel a módszerrel, kiegészítve több száz kutatóhoz eljuttatott kérdôívvel, egy újabb vizsgálat is megerôsítette, hogy a pszichológiai vizsgálatok statisztikai ereje nagyon sok esetben gyenge (Bakker, Hartgerink, Wicherts és van der Maas, 2016). Ez a vizsgálat azt mutatta ki, hogy miközben a kutatók tipikusan intuitív módon határozzák meg a mintanagyságot és azt gondolják, hogy megfelelô mintanagysággal dolgoznak, ez a feltevés formális számítások alapján nem megalapozott. Régóta ismert, hogy az alacsony mintaszám megnöveli a hamis negatív következtetések esélyét, de kevéssé köztudott, hogy az alacsony mintaszám (és ezzel járó alacsony statisztikai erô) a hamis pozitív következtetés esélyét is megnöveli (Button és mtsai, 2013; Gelman és Loken, 2013). Azaz, csak a mintanagyság növelésével csökkenthetô egyidejûleg az elsô- és a másodfajú hiba.

Head és munkatársai (2015) a szakirodalomban közölt szignifikancia- és hatásnagyságértékeket alapul véve végeztek szisztematikus elemzést igen nagy adatmennyiség alapján adatbányászati módszerekkel, nemcsak a pszichológiára vonatkozóan. Ez az elemzés jelentôs mértékú hamis pozitív jelenlétet valószínúsített a vizsgált szakirodalmakban. A hamis pozitív eredmények - ellenôrzés híján - könnyen gyökeret eresztenek, viszont nehezen korrigálhatóak. Jó példa erre a az MMR (bárányhimlő, mumsz, rubeola) oltás és a autizmus kapcsolatát felvetô orvostudományi közlemény története. Andrew Wakefield 1998-ban a The Lancet nevú orvosi lapban publikálta 12 társszerzô- 
vel azt a kis mintán végzett kutatást, amelynek konklúziójaként az autizmus kialakulását az MMR vakcinához kapcsolták (Wakefield éa mtsai, 1998). A bejelentés azonnal széleskörú nyilvánosságot kapott, és megjelent többek között a Nature és az American Scientist lapjain is. Ezzel párhuzamosan meredeken esett a vakcinációt kérô szülők száma, és megugrott a megbetegedett gyermekek száma, elhalálozásokat is beleértve. Késôbb Wakefieldék kutatásával kapcsolatban súlyos aggályok merültek fel. A brit General Medical Council akadémiai csalásnak nyilvánította a kutatást, a cikket a The Lancet 2010-ben visszavonta (Flaherty, 2011). Az erôteljes cáfolatok dacára az oltásellenesség továbbra is makacsul jelen van.

A hamis pozitív eredmények erôs jelenléte aggodalmat váltott ki a válságjelenségekkel kapcsolatos önvizsgálatok során, és a reformmozgalom egyik fố célpontjává vált. A túl sok hamis pozitív eredmény kétségtelenül tévútra viheti, akadályozhatja egy-egy tudományterület elôrehaladását. Ugyanakkor nem reális elvárás, hogy a tudomány sose járjon tévutakon, és a becslési módszerek sem tökéletesek (vö. Jager és Leek, 2014). Az is nyilvánvaló, hogy a hamis negatív eredmények sem kívánatosak - ez az eset azonban nem sok figyelmet kapott a „válságdiskurzusok” folyamán, mivel kevés detektálható negatív eredményt hoznak a kutatások.

\section{A nullhipotézis-teszteléssel kapcsolatos problémák, a statisztika fetisizálása}

A válságjelenségek okainak keresése közben nagy hangsúlyt kapott a statisztika felhasználása a kutatási gyakorlatban. A nullhipotézis-tesztelés („NHST”: Null hypothesis significance testing) bizonyos eloonnyel jár, de állandóan fellángoló viták kísérik (vö. Cohen, 1994; Dienes, 2007; Iacobucci, 2005). Az eljárást számos kritika érte az elmúlt évtizedek alatt, és ezek az utóbbi idôben ismét felerôsödtek (vö. Bárdits és Németh, 2017; Bárdits, Németh és Terplán, 2015; Morrison és Henkel, 2006; Szucs és Ionnidis, 2017).

Dienes (2007) részletesen kifejti, hogy a hipotézisvizsgálat Neyman és Pearson-féle hagyománya a valószínúség objektív, relatív gyakorisági értelmezésén nyugszik, és ez a statisztika nem képes arra, hogy megmondja: egy adott hipotézis milyen valószínúséggel igaz. Az alfa-értékre alapozó eljárás csupán annyit tesz, hogy döntési szabályt hoz arra nézve, hogy mikor fogadjunk el és mikor vessünk el egy hipotézist, így feltételezhetô, hogy hosszú távon viszonylag keveset tévedünk. Az alfa-küszöb nem más, mint egy bizonyos fajta hibaarány, a p-érték azonban nem mondja meg, hogy a hipotézis igaz-e vagy hamis, és valószínúséget sem rendel a hipotézishez. A kutatók viszont jellemzően úgy értelmezik a p-értéket, mintha az a nullhipotézis valószinnúségét fedné fel (Dienes, 2007, ennek okait is kifejti). Az az elképzelés, miszerint a szignifikancia fogalmában bennefoglaltatik a hipotézis valószínúsége, makacs tévhit, sôt logikai hiba (Bárdits, Németh és Terplán, 2016; Dienes, 2007).

Bármennyire konszenzuson alapul a szignifikanciaszint küszöbértéke, mégis egy önkényes határról van szó, amelynek „mágikus” hatalma van eldönteni, hogy egy kutatási eredmény elfogadható-e vagy sem. A küszöbérték használata a komputert megelôzô idôk hagyatéka, amikor is a kézi számítás nehézségei miatt alakult ki ez a megoldás. Mai körülmények között már a pontos szignifikanciaérték közlése ajánlott a 
publikációkban (Ziliak és McClosky, 2009), ez azonban nem oldja meg azt a problémát, hogy a megfelelố p-érték azt az azonnali jó érzést hozza magával, a fenti téves meggyőződésen alapulva, hogy a vizsgálat „sikeres” volt, és az eredmény „igaz”. Ezzel a publikálhatóság egyik feltétele is teljesül, abból a felfogásból kiindulva, hogy „a nem szignifikáns eredmény nem eredmény”. A statisztikai szignifikanciatesztelés rituáléja (Kirk, 1996) azt az illúziót keltheti, hogy bizonyosságot nyertünk az eredmény igazságával kapcsolatban. Paradox módon a statisztika, amit a bizonytalanság tudományaként írnak le, a bizonyosság illúziójának eszközévé válik (Gelman, 2013).

A szignifikáns eredmény nem jelent védelmet vagy mentességet a rossz módszertantól: a nem valid méróeszközök, a rossz mintavétel vagy a kontroll során elkövetett hibák hatásainak következményeitôl (LeBel és Paunonen, 2011). A szakirodalom elemzése azt mutatja, hogy egy-egy területen tartósan alkalmaznak a kutatók alacsony pszichometriai minôségú mérôeszközöket. Ilyennek mutatkozik például több ToM (elmeolvasási) képességet mérō, a 7-13 éves egészséges populáció vonatkozásában használt teszt (Hayward és Homer, 2017). Az is félreértés, hogy a nullhipotézis-tesztelés biztosítékot nyújtana a hamis eredmények szakirodalomban való elszaporodása ellen. Ugyanis a konvencionális szignifikanciaszint nem szab határt a hamis eredmények terjedésének (Pashler és Harris, 2012, Ioannidis, 2005).

Széles körben elkövetett hiba továbbá a hipotézistesztelést exploratív jellegú kutatásoknál alkalmazni, vagy nem is tisztázni, hogy a kutatás exploratív vagy megerôsítô jellegú, mert a statisztikai következtetés csak akkor érvényes, ha egy már elốzetesen világosan megalapozott hipotézis tesztelésére épül. A kutatások fontos és szükségszerú fázisa az exploráció, amikor inkább hipotézisek generálása és elôtesztelése folyik, semmint a már megalapozott hipotézisek tesztelése. Könnyú egy éppen generált hipotézist úgy tekinteni, mint ha az már megalapozott lenne - ez azonban sérti a statisztikai elemzés integritását és a szignifikancia értelmezését (a részletesebb kifejtésre lásd deGroot, 1969/2014; Kerr, 1998, Simmons és mtsai, 2011; John és mtsai, 2012).

A szignifikanciateszteléssel való elégedetlenség újabb hulláma olyan radikális lépéseket is hozott, mint például a Basic and Applied Social Psychology 2015-ös szerkesztôségi állásfoglalása, amely kijelenti, hogy a nullhipotézis-tesztelést érvénytelen eljárásnak tekintik és nem követelik meg a továbbiakban a publikációkban (Trafimow és Marks, 2015). Az erôsen kritikus állásfoglalások sora folytatható (pl. Cumming, 2014; Nuzzo, 2014). Szucs és Ionnidis (2017) is részletesen amellett érvelnek, hogy az NHST-nek nem szabadna dominálnia a biomedikális és pszichológiai kutatásokat. Ezzel együtt feltételezhetô, hogy a nullhipotézis-tesztelés a pszichológiai kutatások eszköztárában fog maradni. A kritikák hulláma azonban megemelte a problémákkal kapcsolatos tudatosságot, átgondolásra és reformokra késztet a pszichológiai kutatásokban alkalmazott statisztikai eljárásokkal kapcsolatban (vö. Dienes, 2007; Klein, 2005; Vargha, 2016).

\section{A „WEIRD” egyetemista mint "modell organizmus”}

Nem javult az a régi probléma sem, hogy a pszichológiai kutatások túlnyomó többsége egyetemistákból álló kényelmi mintavételre támaszkodik. Az amerikai (vagy más nyugati országbeli) egyetemista „modell organizmusként” való alkalmazása tartósan 
jellemzô (becslések szerint tartósan 70-90\% körüli) a pszichológiai és idegtudományi vizsgálatokban (Kimmel, 1998; Peterson, 2001). Az életkorban, szociális helyzetben és gondolkodásmódban is sajátos jellemzókkel rendelkezó egyetemista mintákon nyert eredmények más populációkra történô általánosítása erôsen problematikus. E pont felett azonban rendre átsiklanak a kutatók, akik hajlamosak az általános populációra kiterjeszteni az egyetemista, tipikusan „WEIRD” (white, educated, industrialized, rich, democratic) mintán nyert eredményeket (Editorial, Nature, Neuroscience, 2010; Henrich, Heine, Norenzayan, 2010).

Mindez kérdéseket vet fel a megismételhetôséggel kapcsolatban is. A megismételhetôség állandóságot, azonosságot feltételez, holott a szociokulturális jelenségek erôsen kontextusfüggóek, és a populációk sokban eltérôek egy kultúrán belül is, hát még kultúrák között. Az univeralizmus még olyan jelenségekkel kapcsolatban sem feltétlenül tartható, mint a vizuális illúziók; a Müller-Lyer-illúziót például egyes afrikai populációk nem vagy kevésbé erôsen észlelik, mint a nyugati világban élô általános populáció (Henrich, Heine, Norenzayan, 2010).

A fentiek érzékeltetik, hogy a 2010-es években alapvetô kérdések merültek fel a tudományos pszichológia múködésével kapcsolatban. Ilyen átfogó kérdés az, hogy mi számít értékes tudománynak? Mi a helye és szerepe az új eredményeknek, és menynyire fontos, hogy az eredmények szilárdak legyenek? Mit minôsítsünk elfogadható módszertani rugalmasságnak és mit elfogadhatatlannak? Egyáltalában, hogyan tud az eddiginél jobban múködni a pszichológiai kutatás? A válaszok keresése most is folyik, de már eddig is értékes lépések történtek a problémák megoldása érdekében.

\section{REFORMMOZGALOM A JÓ ELJÁRÁSOK MEGERÖSÍTÉSE ÉRDEKÉBEN}

Van aki reformmozgalomként, van aki módszertani forradalomként értékeli a jó eljárások megerôsítésére és a rendszerszintû hibák kiküszöbölésére történt kezdeményezések sorát. Biztos azonban, hogy sokféle változás indult el az elmúlt években. A bizalmi válság egyik oka abban állt, hogy úgy tûnt: a pszichológiai kutatások elfogadott gyakorlatában a kutatók sok mindent megtehettek annak érdekében, hogy bizonyítékot találjanak arra, amire bizonyítékot szerettek volna találni. Ezt a tágabb tudományos intézményesített rendszer akaratlanul is inkább elôsegítette, semmint gátolta. A jelentôs mértékben „grass root” reformmozgalom egyik fó célja a bizonyítási eljárás integritásának helyreállítása a pszichológiai kutatások széles spektrumában („evidentiary value movement”, Finkel, Eastwick és Reis, 2015).

A mozgalom az ismertetett elôzményekból fokozatosan nôtt ki. Ide tartozik a The Open Science Collaboration (2012) és az ennek keretében létrejött Open Science Framework $(\mathrm{OSF})$, amely a kutatások megosztására szolgáló nyitott platform. A mozgalom részének tekinthetôek azok a weboldalak és blogok is, amelyek a feltárt hiányosságokat segítenek orvosolni, így a PsychFileDrawer.org (megismétlésre irányuló kutatások archívuma); a PsychDisclosure.org (olyan platform, amelyen kutatók azokat a részleteket hozhatják nyilvánosságra, amelyek a publikációkból kimaradnak), vagy például a már említett Retraction Watch (amely a már publikált kutatások visszavonását tartja számon). 
A reformmozgalom keretében a következó foobb ajánlások és újítások fogalmazódtak meg:

\section{A kutatási tervek elöregisztrációja}

A kutatási gyakorlat új eleme az előregisztráció. A holland deGroot volt az elsô, aki ezzel a javaslattal élt (deGroot, 1969/2014), a hatás azonban igazán csak a 2010-es években felismert problémák nyomán kezd érvényesülni. Az előregisztráció azt jelenti, hogy a kutató/kutatócsoport önként vállalja, hogy az adatgyújtés megkezdése elôtt egy archívumban elhelyezi az adatgyújtés és elemzés részletes tervét és protokollját. Fontos az alkalmazott mérôeszköz elôregisztrációja is, valamint hogy a szerzốk nyilatkozzanak arról, hogy a kutatás exploratív vagy megerôsítô jellegú. A gyakorlatban az elôregisztráció védett online elhelyezést jelent, amelyhez egy megjelölt dátum („embargó”) lejártáig csak korlátozott jogosultsággal lehet hozzáférni.

Az érvelés szerint az elôregisztráció gátolja (vagy legalábbis csökkenti) a rossz kutatási szokásokat, növeli a megismételhetôség esélyét, és a publikációs torzulásra is kedvezôen hat, mivel a negatív eredményeknek is nyomuk marad, feltételezve, hogy késôbb az eredmények is bekerülnek az archívumba (Chambers, 2014; Wagenmakers és mtsai, 2012; Nosek és Lindsay, 2018). Az előregisztráció ma viszonylag könnyen megvalósítható, erre több platform áll rendelkezésre (például a már említett Open Science Framework; OSF). A Psychological Science c. folyóirat 2011-ben kezdeményezóként lépett fel és különbözô ösztönzôket indított, hogy a szerzôk kutatásukat előregisztrálják. A folyóirat vállalta a közvetlen megismétléses vizsgálatok publikálását akár szignifikáns, akár nem szignifikáns azok eredménye (Association for Psychological Science, n.d.; Mission Statement).

Az elôregisztráció egyik fó ellenérve az, hogy túlszabályozottá teszi a kutatás folyamatát, megköti a kutató kezét, és így akadályozza a kutatás közbeni felfedezések lehetôségét (Goldin-Meadow, 2016). Azt is figyelembe kell venni, hogy az előregisztráció nem minden típusú kutatás esetében alkalmazható egyforma módon (lásd pl. longitudinális vizsgálatok; vö. Finkel, Eastwick és Reis, 2015). Az átláthatóság azonban önmagában is érték. Az átláthatóság magában foglalja a kutatások módszertanának minél részletesebb ismertetését a publikációkban, a nyers adatok és a nem publikált elemzések megosztását, és az esetleges szponzorációk nyilvánosságra hozatalát.

\section{Exploráció és megerôsités elválasztása, mintanagyság, statisztikai erô}

A metodológus deGroot - másokkal együtt - hangsúlyozta az exploratív és bizonyító vizsgálatok különbségtételének fontosságát (deGroot, 1969/2014; Wagenmakers és mtsai, 2012). A klinikai kutatásokban különösen nagy jelentôsége van (de nemcsak ott) a kettố megkülönböztetésének. A felfedezô fázisban kis mintákon, különbözô módszertani eljárások próbálgatásával lehet a felmerülő hipotéziseket elsôdlegesen tesztelni. Ettôl elkülönül a kutatásnak az a fázisa, amikor nagy bizonyító erốt kell alkalmazni, hogy az adott hipotézisról kiderüljön, mennyire igazolható. Fent említett hibás (de elterjedt) gyakorlat az, amikor a kutató a kis mintán végzett szignifikáns eredményt a hipotézisre nézve magas bizonyító erejúnek és általánosíthatónak tekinti.

A statisztikai irodalom hangsúlyozza, hogy csak a megerôsító jellegú vizsgálat nevezhető valódi hipotézistesztelésnek, ez az, amelyre vonatkozóan valódi értelme van 
a statisztikai tesztek alkalmazásának (Button és mtsai, 2013; Vargha, 2000). Ennek érdekében hangsúlyozott ajánlás a kvantitatív kutatás „arany sztenderdje”: a kezdeti kis volumenú felfedezô vizsgálatokra épülő, nagy statisztikai erôvel bíró megerôsítô célú vizsgálat, amely adott esetben falszifikáló erôvel is bírhat. A statisztikai erô öszszetett feltételeket jelent: elegendôen nagy minta szükséges a hatás detekciójához; magának a hatásnak is elegendôen nagynak kell lennie; továbbá a mérôeszközöknek is érvényesnek és megbízhatónak kell lenniük (Dienes, 2007). Összességében tehát hangsúlyozott ajánlás a felfedezô és a megerôsítő kutatási kontextus elhatárolása, és a statisztikai erô növelése.

Ezzel együtt erôsen ajánlott elhagyni a nullhipotézisre támaszkodást mint egyetlen módszert, és kiegészíteni azt a hatásnagyságra és a konfidencia-intervallumra vonatkozó információkkal, továbbá elôtérbe helyezni a bayesiánus statisztika alkalmazását (errôl részletesen lásd: Dienes, 2007; Henson és Smith, 2000). A kis mintákon ki lehet mutatni erôs hatásokat, de a gyengébb (ettôl még potenciálisan fontos) hatásokat csak nagy mintákon lehet kimutatni. Az eredményeket viszont a hatásnagyság mutatóival kell jellemezni, függetlenül attól, hogy kis vagy nagy mintán történt-e az adatfelvétel. Azon túl, hogy van-e hatás, az érdekes kérdés az, hogy ez a hatás mekkora.

\section{Megismétlés, megismétlés}

A Megismétlési Projekt középpontba állította a közvetlen megismétlés szerepét. Egyetértés alakult ki arra nézve, hogy a megismétlés nem csodaszer, de ahhoz hogy hitelt nyerjen egy vizsgálati eredmény, megismételhetônek kell lennie független kutatócsoportok által. A megismétlés a tudás megszilárdításának, és egyúttal a tudomány önkorrekciójának az eszköze. Ugyanakkor mások munkájának a megismétlése idő- és energiaigényes vállalkozás, amelyre nehéz rábírni a kutatókat. Fontos lépések és javaslatok születtek ennek a kérdésnek az elômozdítására is.

Megjelent egy új publikációs múfaj, a „regisztrált megismétlési közlemény” („registered replication report", RRR), amely szerint több független labor egységes protokoll alapján végez pontos megismétlést. 2011-ben a Perspectives on Psychological Science c. folyóirat bevezette az ilyen publikációk közlését (Simons, Holcombe és Spellman, 2014). A cél eléréséhez vinnének közelebb az „ismételd meg és terjeszd ki” típusú kutatások is, amelyek összekötnék a közvetlen és a koncepcionális megismétlést (Open Science Collaboration, 2015). Nagy lehetôségek rejlenek a kollektív (crowdsourcing alapú) nagy kutatási projektekben, mint amilyen maga a Megismétlési Projekt is volt. Ezekben sok kutató egyenként viszonylag kevés munkát tesz bele a közös protokoll alapján folyó kutatásba, amely azonban a sok közremúködő folytán „megaprojektté” tud válni (Open Science Communication, 2015).

Javaslat született a „Megismétlési Index” („Replicability Index”, R-Index) fogalmának bevezetésére, amely egy kutatási területen született eredmények megismételhetôségét jósolja be (Schimmack, 2016). Más javaslatok a BA, MA és PhD diákok bevonását javasolják; eszerint sokkal nagyobb mértékben kellene bátorítani ebben a közegben a megismétlésre épülô kutatásokat, amelyek a szakmai szocializációt is segítenék (Frank és Saxe, 2012). Az Open Science Foundation keretében végzett Collaborative Replications and Education Project (https://osf.io/wfc6u/) például azonosítja azokat a kutatá- 
sokat, amelyeket BA oktatás keretében megismétlésre ajánlanak, pontos instrukciókat adva a megismétléshez, és platformot biztosítva az eredmények feltöltéséhez.

Ugyanakkor a megismétlés kapcsán is felmerül az a szempont, miszerint az nem feltétlenül alkalmazható mindenféle típusú pszichológiai vizsgálatra (Finkel, Eastwick és Reis, 2015). A szociokulturális jelenségek kontextusfüggố, változékony jellegéból adódó korlátokat is figyelembe kell venni. Továbbá azt is, hogy a megismétlésnek is csak akkor van bizonyító ereje, ha megfelelő statisztikai erôvel rendelkezik a vizsgálat (Francis, 2012).

\section{Változtatni kell az ösztönzési és a kommunikációs rendszeren}

Az ösztönzési rendszer megváltoztatása heves vitákat kiváltó kérdés, ami messze nem csak a pszichológiát érinti. Érdekes fejlemény, hogy a Journal Impakt Factor (JIF) heves bírálata bontakozott ki az Amerikai Sejtbiológiai Társaság (American Society for Cell Biology, ASCB) 2012. decemberi San Franciscó-i ülésén, amely egy diszciplinákon átívelő manifesztum megfogalmazását eredményezte. A DORA néven ismertté vált nyilatkozatot (San Francisco Declaration on Research Assessment, é. n.) 82 tudományos szervezet jegyezte, köztük vezetô folyóiratok szerkesztôségei, kemelkedô kutatóhelyek és tudománymetrikával foglalkozó szervezetek. A DORA részletesen elemzi a JIF hiányosságait, és elutasítja a JIF egyénekre vonatkoztatott használatát. Az ajánlások arra szólítanak fel, hogy minden tudományág gondolja át saját maga számára a minôségi kutatás koncepcióját, és a tudományos teljesítmények széles spektrumának értékét. A DORA ezzel összefüggésben ösztönzi az alternatív értékelési rendszerek kidolgozását, és a tudományos közösségek részvételét ebben a folyamatban. Megjelent az „altmetrics" fogalma: ez azokra a hatásmérô mutatókra terjed ki, amelyek az online publikációmegosztás ma egyre terjedô tudományos ökoszisztémáját jellemzik (pl. letöltések száma a Reserach Gate vagy az academia.edu oldalakon, vö. Priem, Taraborelli, Groth és Neylon, 2010).

\section{AZ ÖNKORREKCIÓ HAGYOMÁNYOS ÉS „HI-TECH” FORMÁI}

Az önkorrekció a tudomány alapjellemzője (Merton, 1973). De mit jelent ez ténylegesen? A tudomány egy adott korszakban heterogén státuszú és validitású eljárások, módszerek és bizonyítékok halmaza, amelyben ismeretlen mértékben van egyszerre jelen idôtálló tudás és ennek az ellenkezôje, miközben mindez folytonosan változik. Az önkorrekció az a nagyobb idôsíkban kibontakozó folyamat, amelyik kirostálja az érvénytelen tudást. Helytelen azonban azt gondolni, hogy az önkorrekció magától érvényesülố automatizmus. Ioannidis (2012) arra figyelmeztet, hogy a nem valós eredmények akár hosszú távon is beépülhetnek. Az önkorrekció az intézményes és az egyéni szereplők közös felelôssége, amiért aktív erôfeszítést kell tenni. Fel kell ismerni, ha egy adott idôszakban az önkorrekciós mechanizmusok legyengülnek, és tenni kell megerôsítésük érdekében. Ennek hagyományos csatornája a tudományos közegre jellemzó kritika és önkritika, az eredmények, elméletek és módszertani eljárások felülvizsgálatára való készenlét. 
A reformmozgalom ajánlásai is ezen általános cél érdekében lépnek fel, azonban high-tech oldalról radikálisabb megoldások is születnek. Erre példa a publikációk programozott algoritmusok által való kritikai átvizsgálása. A holland Tilburg Egyetem Metakutatási Központjának (Meta-Research Center) egyik kutatócsoportja Michèle Nuitjen vezetésével olyan programot fejlesztett ki, amelyik a világhálón megjelent publikációk statiszikai részeit (a szerzô beleegyezése és tudta nélkül) kritikai elemzésnek veti alá. Az eljárás nagy felzúdulást keltett, amikor a világhálóra felkerült azon publikációk listája, amelyeket a program hibásnak talált (az érintett szerzók pedig egy utólagosan küldött emailból értesülhettek errôl, vö. Buranyi, 2017). Ettôl függetlenül is, ma többen feladatuknak érzik (többnyire fiatal kutatók, és néhány tudománnyal foglalkozó újságíró), hogy aktívan ellenôrizzék a megjelent publikációk megalapozottságát, s nyilvánosságra hozzák, ha gyanús jeleket észlelnek (Brian Wansink lebukását is ilyen „nyomozás” okozta).

\section{KONKLÚZIÓ}

A 2010-es évek válsága tekinthetô a régóta hurcolt problémák (statisztikai szignifikancia, publikációs torzulás, hamis pozitív eredmények) és az újabb körülmények között született problémák (csalások felszaporodása, hiteltelen publikációk megjelenése, tudományos kommunikáció problémái) egyvelegének. Több régi problémát az új körülmények tettek hangsúlyosabbá. Így például régebben is történtek tudományos csalások, és feltehetóen jelen voltak az ideális sztenderdeket el nem éró kutatói eljárások, ezek a jelenségek azonban felerôsödtek, nem kis mértékben (de nem egyedül) a produktivitásra irányuló nyomás következtében.

Amennyire szerteágazóak a problémák, olyannyira nehéz a megoldások megtalálása.

A Nature 2017/551-es száma öt kiemelkedő statisztikust kért fel arra, hogy tegyenek javaslatot, miként lehetne jobbá tenni a tudományos kutatásokat (Leek, McShane, Gelman, Colquhoun, Nuijten, 2017). Jeff Leek, a Johns Hopkins School of Public Health kutatója az emberi tényezôt emelte ki: a komputerek és a programozott statisztikai eljárások hatalmas adat- és eredménytömeget dobnak ki, de mindig a tudományos kutató az, akinek értelmeznie kell ezeket. Jobban kell értenünk a kutatók gondolkodásmódját, és ennek figyelembevételével kell felvérteznünk óket a korszerú módszertani és adatelemzési technikákkal.

Blakeley McShane és Andrew Gelman (a Northwestern és a Columbia Egyetem kutatói) a statisztikai szignifikanciára épüló gondlkodásmód elhagyását említették. A lényeg nem a p-érték elvetése, hanem az, hogy a kutatók ezt csak egy mutatóként kezeljék, tekintetbe véve a hatásnagyságot, valamint a kutatási dizájn erejét és az adatok minôségét. A lényeg az, hogy a kutatók ne a hipotézismegtartás, illetve -elvetés dichotómiájában gondolkodjanak, hanem az eredmények komplexen értékelt megalapozottságában. David Colquhoun (University College London) és Michèle Nuitjen (Tilburg University) a hamis pozitív eredmények kockázatát emelték ki, hangsúlyozva az elooregisztráció és az átláthatóság fontosságát. Steven Goodman (Stanford University) a „tudományos kultúra” döntő szerepét említette: az egyének a tudományos kö- 
zösségek uralkodó normáihoz igazodnak. A megfelelố tudományos kultúra kialakítása és fenntartása közös feladat, amelyben részt kell venniük a folyóiratoknak, a finanszírozóknak és az egyes kutatóknak, különösképpen pedig a vezetô kutatóknak.

A tudományos munka jellemzôi jelentôsen átformálódnak a jelenkor feltételrendszerében. Ennek egyik szembetûnố következménye a tudományos szféra gyors növekedése, és a tudományos produktivitás felgyorsulása. A tudomány hatékonysága és hasznossága, csakúgy, mint a hatásmérés, elsôdleges kérdések egy egyre inkább tudományra és digitális technológiákra épülő világban. Mindennél fontosabb azonban a tudomány hitelességének megtartása.

Brian Nosek és munkatársai (Nosek és Bar-Anan, 2012; Nosek, Spies és Motyl, 2012) egy olyan „utópiát” vázolnak fel a jövőre nézve, ahol megvalósul a tudományos eredmények nyílt hozzáférhetôsége és átláthatósága, és a tudomány múvelését elsôsorban a valóság feltárásának szempontja, nem pedig a publikálhatóság vezérli. Lehet, hogy ez az utópia még várat magára, de annak szemtanúi vagyunk, hogy a tudomány átalakuláson megy keresztül és új utakat nyit meg (vö. Bartling és Friesike, 2014). A 2010-es évek tanulságai bizonyosan fontosak a jelen és a jövô számára.

\section{IRODALOM}

Akst, J. (2012). Scientists review own papers. The Scientist, Online, 2012 Oct.3. https://www. the-scientist.com/?articles.view/articleNo/32810/title/Scientists-Review-Own-Papers / Letöltve: 2017.12.20.

Alcock, J. (2003). Give the null hypothesis a chance: Reasons to remain doubtful about the existence of psi. Journal of Consciousness Studies, 10(6-7), 29-50.

Anderson, M. S., Ronning, E. A., De Vries, R., \& Martinson B. C. (2007). The perverse effects of competition on scientists' work and relationships. Science and Engineering Ethics. 13, 437-461.

Bakker, M., Hartgerink, C. H., Wicherts, J. M., \& van der Maas, H. L. (2016). Researchers' intuitions about power in psychological research. Psychological Science, 27(8), 1069-1077.

Banks, G. C., Rogelberg, S. G., Woznyj, H. M., Landis, R. S., \& Rupp, D. E. (2016). Evidence on questionable research practices: The good, the bad, and the ugly. Editorial. Business and Psychology, 31(3), 323-338.

Barch, D. M, \& Yarkoni, T. (2013). Introduction to the special issue on reliability and replication in cognitive and affective neuroscience research. Cognitive, Affective, and Behavioral Neuroscience, 13, 687-689.

Bárdits A., \& Németh R. (2017). A statisztikai szignifikanciateszt rítusa - kortárs kritikák; a rítus a szociológiában. Szociológiai Szemle, 27(1), 119-125.

Bárdits A., Németh R., \& Terplán G. (2016). Egy régi probléma újra elôtérben: a nullhipotézis szignifikanciateszt téves gyakorlata. Statisztikai Szemle, 94(1), 52-75.

Bargh, J. A., Chen M., \& Burrows, L. (1996). Automaticity of social behavior: direct effects of trait construct and stereotype-activation on action. Journal of Personality and Social Psychology, 71, 230-244.

Bartling, S., \& Friesike, S. (2014). Opening science: The evolving guide on how the internet is changing research, collaboration and scholarly publishing. Springer Open. Springer International Publishing.

Begley, C. G., \& Ellis, L. M. (2012). Drug development: Raise standards for preclinical cancer research. Nature, 483(7391), 531-533. 
Bem, D. J. (2011). Feeling the future: Experimental evidence for anomalous retroactive influences on cognition and affect. Journal of Personality and Social Psychology, 100(3), 407-425.

Binswanger, M. (2014). Excellence by nonsense: The competition for publications in modern science. In S. Bartling \& S. Friesike (Eds). Opening science: The evolving guide on how the internet is changing research, collaboration and scholarly publishing. Springer Open (pp. 49-72). Springer International Publishing.

Bornmann, L., \& Mutz, R. (2015). Growth rates of modern science: A bibliometric analysis based on the number of publications and cited references. Journal of the Association for Information Science and Technology, 66(11), 2215-2222.

Bozzo, A., Bali, K., Evaniew, N., \& Ghert, M. (2017). Retractions in cancer research: a systematic survey. Research Integrity and Peer Review, 2(1), 5.

Brechman, J. M., Lee, C. J., \& Cappella, J. N. (2011). Distorting genetic research about cancer: from bench science to press release to published news. Journal of Communication, 61(3), 496-513.

Brown, P. (2012). Nothing but the truth. Are the media as bad at communicating science as scientists fear? EMBO Reports, 13(11), 964-967.

Buranyi, S. (2017). The hi-tech war on science fraud. The Guardian, online: 2017.02.01. https:// www.theguardian.com/science/2017/feb/01/high-tech-war-on-science Letöltve: 2018.05.19.

Button, K. S., Ioannidis, J. P., Mokrysz, C., Nosek, B. A., Flint, J., Robinson, E. S., \& Munafò, M. R. (2013). Power failure: why small sample size undermines the reliability of neuroscience. Nature Reviews Neuroscience, 14(5), 365-376.

Carney, D. R., Cuddy, A. J., \& Yap, A. J. (2010). Power posing: Brief nonverbal displays affect neuroendocrine levels and risk tolerance. Psychological Science, 21(10), 1363-1368.

Chambers, C. (2014). Psychology's 'Registration Revolution.'. The Guardian. Science section, online: 2014 May 2. https:/ /www.theguardian.com/science/head-quarters/2014/may/20/ psychology-registration-revolution Letöltve: 2017.12.22.

Cohen, J. (1995). The earth is round ( $\mathrm{p}<.05$ ): Rejoinder. American Psychologist, 50, 997-1103.

Cuddy, A. (2015). Presence: Bringing your boldest self to your biggest challenge. New York: Little, Brown and Company.

Cumming, G. (2014). The new statistics: Why and how. Psychological Science, 25(1) 7-29.

Csaba L., Szentes T., \& Zalai. E. (2014). Tudományos-e a tudománymérés? Megjegyzések a tudománymetria, az impakt faktor és az MTMT használatához. Magyar Tudomány, 175(4), 442-466.

De Groot, A. D. (1969/2014). The meaning of "significance" for different types of research. Translated and annotated by Eric-Jan Wagenmakers et. al. Acta Psychologica, 148, 188-194.

Dienes Z. (2007). Mitól tudomány a pszichológia? A tudományos és statisztikai következtetés alapjai. Budapest: Akadémiai Kiadó.

Dilworth, C. (2008). Scientific progress. A study concerning the nature of the relation between successive scientific theories. Dordrecht: Kluwer Academic Publishers.

Dominus, S. (2017) When the revolution came for Amy Cuddy. The New York Times, online: 18.10.2017. https://www.nytimes.com/2017/10/18/magazine/when-the-revolution-camefor-amy-cuddy.html Letöltve: 2017.12.20.

DORA / Declaration on Research Assessment (2017). Annual Meeting of The American Society for Cell Biology (ASCB) in San Francisco, CA, (December 16, 2012), Online: http:// www.ascb.org/wp-content/uploads/2017/07/sfdora.pdf Letöltve: 2017.09.23.

Doyen, S., Klein, O., Pichon, C. L., \& Cleeremans, A. (2012). Behavioral priming: it's all in the mind, but whose mind? PloS One, 7(1), e29081.

Durante, K. M., Rae, A., \& Griskevicius, V. (2013). The fluctuating female vote: Politics, religion, and the ovulatory cycle. Psychological Science, 24(6), 1007-1016. 
Editorial (2010). The university student as a model organism. Nature, Neuroscience, 13(5), 521. https://www.nature.com/articles/nn0510-521.pdf Letöltve: 2018.10.28.

Editorial (2011). Combating scientific misconduct. National Cell Biology, 13(1), 1.

Engber, Daniel (2017). The Trials of Amy Cuddy. A feminist psychologist was dragged through the mud for her mistakes. Did she deserve it? Online: 2017. Oct. 19. http:/ /www.slate.com/ articles/health_and_science/science/2017/10/did_power_posing_guru_amy_cuddy_ deserve_her_public_shaming.html Letöltve: 2017.12.20.

Errington, T. M., Iorns, E., Gunn, W., Tan, F. E., Lomax, J., \& Nosek, B. A. (2014). An open investigation of the reproducibility of cancer biology research. Elife, 3, e04333.

Fanelli, D. (2009). How many scientists fabricate and falsify research? A systematic review and meta-analysis of survey data. PLoS One, 4(5), 1-11.

Fanelli, D. (2012). Negative results are disappearing from most disciplines and countries. Scientometrics, 90, 891-904.

Fanelli, D. (2010). Do pressures to publish increase scientists' bias? An empirical support from US States Data. PloS One, 5(4), e10271.

Fanelli, D. (2010). Positive" results increase down the hierarchy of the sciences. PloS One, 5.4: e10068.

Fanelli, D. (2011). Negative results are disappearing from most disciplines and countries. Scientometrics, 90, 891-904.

Fang, F. C., Steen, R. G., \& Casadevall, A. (2012). Misconduct accounts for the majority of retracted scientific publications. Proceedings of the National Academy of Sciences, 109(42), 17028-17033.

Fang, F. C., \& Casadevall, A. (2015). Competitive science: is competition ruining science? Infection and Immunity, IAI-02939.

Ferguson, C. J., \& Heene, M. (2012). A vast graveyard of undead theories: Publication bias and psychological science's aversion to the null. Perspectives on Psychological Science, 7(6), $555-561$.

Fiedler, K. (2011). Voodoo correlations are everywhere - not only in neuroscience. Perspectives on Psychological Science, 6(2), 163-171.

Finkel, E. J., Eastwick, P. W., \& Reis, H. T. (2015). Best research practices in psychology: Illustrating epistemological and pragmatic considerations with the case of relationship science. Journal of Personality and Social Psychology, 108(2), 275.

Flaherty, D. K. (2011). The vaccine-autism connection: a public health crisis caused by unethical medical practices and fraudulent science. Annals of Pharmacotherapy, 45(10), 1302-1304.

Francis, G. (2012). Too good to be true: Publication bias in two prominent studies from experimental psychology. Psychonomic Bulletin E Review, 19(2), 151-156.

Franco, G. (2013). Research evaluation and competition for academic positions in occupational medicine. Archives of Environmental E Occupational Health, 68(2), 123-127.

Frank, M. C., \& Saxe, R. (2012). Teaching replication. Perspectives on Psychological Science, 7(6), $600-604$.

Gadbury GL, Allison DB (2012). Inappropriate fiddling with statistical analyses to obtain a desirable p-value: Tests to detect its presence in published literature. PLoS One, 7(10): e46363. https://doi.org/10.1371/journal.pone.0046363 Letöltve: 2017.12.10.

Galak, J., LeBoeuf, R. A., Nelson, L. D., \& Simmons, J. P. (2012). Correcting the past: Failures to replicate psi. Journal of Personality and Social Psychology, 103: 933-948.

Gelman, A. (2013). How can statisticians help psychologists do their research better? Statistical Modeling, Causal Inference, and Social Sciences Blog. Online: 2013 May 17. http://andrewgelman.com/2013/05/17/how-can-statisticians-help-psychologists-do-their-research-better/ 
Gelman, A., \& Loken, E. (2013). The garden of forking paths: Why multiple comparisons can be a problem, even when there is no "fishing expedition". Online: 2013. Nov. 14. http://www. stat.columbia.edu/ gelman/research/unpublished/p_hacking.pdf Letöltve: 2017.09.20.

Gelman, Andrew \& Fung, K. ( 2016). The Power of the "Power Pose" Amy Cuddy's famous finding is the latest example of scientific overreach. Slate Online: 2016.01.19. http://www.slate. com/articles/health_and_science/science/2016/01/amy_cuddy_s_power_pose_research_ is_the_latest_example_of_scientific_overreach.html Letöltve: 2017.10.01.

Goldin-Meadow, S. (2016). Why preregistration makes me nervous. APS Observer, 29(7). https:/ / www.psychologicalscience.org/observer/why-preregistration-makes-me-nervous Letöltve: 2018.12.06.

Hauser, M. D., Weiss, D., \& Marcus, G. (2002). RETRACTED: Rule learning by cotton-top tamarins. Cognition, 86(1), B15-B22.

Hayward, E. O., \& Homer, B. D. (2017). Reliability and validity of advanced theory-of-mind measures in middle childhood and adolescence. British Journal of Developmental Psychology, 35(3), $454-462$.

Head, M. L., Holman, L., Lanfear, R., Kahn, A. T., \& Jennions, M. D. (2015). The extent and consequences of p-hacking in science. PLoS Biology, 13(3), e1002106.

Heene, M., \& Ferguson, C. J. (2017). Psychological science's aversion to the null, and why many of the things you think are true, aren't. In S.O. Lilienfeld, \& I.D. Waldman, (Eds). Psychological science under scrutiny: Recent challenges and proposed solutions (pp. 34-52). John Wiley \& Sons.

Henrich J., Heine S. J., \& Norenzayan, A. (2010). The weirdest people in the world? Behavior and Brain Sciences, 33(2-3), 61-83.

Henson, R. K., \& Smith, A. D. (2000). State of the art in statistical significance and effect size reporting: A review of the APA Task Force report and current trends. Journal of Research $\mathcal{E}^{\circ}$ Development in Education, 33, 285-296.

Hibbing, J. R., Smith, K. B., \& Alford, J. R. (2014). Predisposed: Liberals, conservatives, and the biology of political differences. New York and London: Routledge.

Iacobucci, D. (2005). On p-values. Journal of Consumer Research, 32(1) 6-11.

Interlandi, J . 2006. An unwelcome discovery. New York Times, New York, NY. http:/ /www.nytimes. com/2006/10/22/magazine/22sciencefraud.html?pagewanted=all\&_r=0. Letöltve: 2018.10.28.

Ioannidis, J. P. (2005). Why most published research findings are false. PLoS Medicine, 2(8), e124.

Ioannidis, J. P. (2012). Why science is not necessarily self-correcting. Perspectives on Psychological Science, 7(6), 645-654.

Jager, L.R., \& Leek, J.T. (2014). An estimate of the science-wise false discovery rate and application to the top medical literature. Biostatistics, 15: 1-12.

Jasny, B. R., Chin, G., Chong, L., \& Vignieri, S. (2011). Data replication and reproducability. Again, and again, and again. Science, December 2., 334(6060):1225.

John, L. K., Loewenstein, G., \& Prelec, D. (2012). Measuring the prevalence of questionable research practices with incentives for truth telling. Psychological Science, 23(5) 524-532.

Johnson, J. P. (2011). Cancer researcher fabricated data. The Scientist, 2011. Aug. 11. Online: 2011. August 11. https://www.the-scientist.com/?articles.view/articleNo/31028/title/ Cancer-Researcher-Fabricated-Data/ Letöltve: 2018.01.24.

Johnson, C. S., Smeesters, D., \& Wheeler ,S. C. (2012). Retraction of Johnson, Smeesters, and Wheeler (2012). Journal of Personality and Social Psychology, 103: 605.

Kahnemann, D. (2011). Thinking fast and slow. New York: Farrar, Straus and Giroux. 
Kennedy, J. E. (2015). Critique of Cumming's „new statistics” for psychological research: A perspective from outside psychology. Online: http://jeksite.org/psi/critique_new_stat.pdf and http://jeksite.org/psi/critique_new_stat.htm Letöltve: 2017.03.04.

Kerr, N. L. (1998). HARKing: Hypothesizing after the results are known. Personality and Social Psychology Review, 2(3), 196-217.

Kimmel, A. J. (1998). In defence of deception. American Psychologist, 53, 803-804.

Klein, D. F. (2005). Beyond significance testing: Reforming data analysis methods in behavioral research. American Journal of Psychiatry, 162(3), 643-a.

LeBel, E. P., \& Peters, K. R. (2011). Fearing the future of empirical psychology: Bem's (2011) evidence of psi as a case study of deficiencies in modal research practice. Review of General Psychology, 15(4), 371-379.

LeBel, E. P., \& Paunonen, S. V. (2011). Sexy but often unreliable: The impact of unreliability on the replicability of experimental findings with implicit measures. Personality and Social Psychology Bulletin, 37(4), 570-583.

Leek J., McShane B., Gelman A., Colquhoun D., Nuijten, M. (2017). Five ways to fix statistics: Share analysis plans and results. Nature, 551, 557-559.

Lisberger, S. G. (2013). Sound the alarm: Fraud in neuroscience. In Cerebrum: the Dana Forum on Brain Science, (May-June). Dana Foundation. Online: May. 02. http://dana.org/Cerebrum/2013/Sound_the_Alarm_Fraud_in_Neuroscience/ Letöltve: 2018.01.24.

Lock, S., Wells, F. O. \& Farthing M. J. (Eds) (2001). Fraud and misconduct in biomedical research. London: BMJ Books.

Lutus, P. (2017). Psychology and neuroscience. Ont he transition from psychology to neuroscience. Arachnoid.com blog, Online: Oct. 18. https://arachnoid.com/psychology_and_neuroscience/ Letöltve: 2018.01.21.

Makel, M. C., Plucker, J. A., \& Hegarty, B. (2012). Replications in psychology research: How often do they really occur? Perspectives on Psychological Science, 7(6), 537-542.

Marszalek, J. M., Barber, C., Kohlhart, J., \& Cooper, B. H. (2011). Sample size in psychological research over the past 30 years. Perceptual and Motor Skills, 112(2), 331-348.

Marton J., Varró A., \& Varró V. (2004). Impaktfaktor és tudományos teljesítmény. Magyar Tudomány, 49(12), 1395-1403.

McCook, Alison (2017). When a paper retracts 107 papers for fake reviews, it pays a price. Retraction Watch. Online: 2017. August 16. http://retractionwatch.com/2017/08/16/journalretracts-107-papers-fake-reviews-pays-price/\#more-51443 Letöltve: 2017.09.20.

Meehl, P. E. (1967). Theory-testing in psychology and physics: A methodological paradox. Philosophy of Science, 34(2), 103-115.

Merton, R. K. (1973). The sociology of science: Theoretical and empirical investigations. Chicago: University of Chicago Press.

Michigan State University. 'Power poses' don't work, eleven new studies suggest. ScienceDaily. Online: 2017 September 11. www.sciencedaily.com/releases/2017/09/170911095932.htm

Miller, A. N., Taylor, S. G., \& Bedeian, A. G. (2011). Publish or perish: academic life as management faculty live it. Career Development International, 16(5), 422-445.

Mitchell, J. (2014). On the evidentiary emptiness of failed replications. Working paper. http://jasonmitchell.fas.harvard.edu/Papers/Mitchell_failed_science_2014.pdf Letöltve: 2018.01.22.

Moore, A. (2006). Bad science in the headlines. Who takes responsibility when science is distorted in the mass media? EMBO Reports, 7(12), 1193-1196.

Morrison, D. E. \& Henkel, R. E. (Eds) (2006). The Significance Test Controversy: A Reader. New Brunswick: Aldine Transaction Publishers.

Mullard, A. (2011). Reliability of 'new drug target' claims called into question Nature Reviews Drug Discovery, 10, 643-644 
Neuroskeptic. (2012). The nine circles of scientific hell. Perspectives on Psychological Science, 7 , 643-644.

Newcomer, E. P. \& Spitzer, E. A. L. (2010). Marc Hauser's fall from grace. The Harvard Crimson www. thecrimson.com/article/2010/9/14/hauser-lab-research-professor/ Letöltve: 2017. 12.20.

Nosek, B. A., \& Bar-Anan, Y. (2012). Scientific utopia: I. Opening scientific communication. Psychological Inquiry, 23(3), 217-243.

Nosek, B. A., Spies, J. R., \& Motyl, M. (2012). Scientific utopia: II. Restructuring incentives and practices to promote truth over publishability. Perspectives on Psychological Science, 7(6), $615-631$.

Nosek, B. A., \& Lindsay, D. S. (2018). Preregistration becoming the norm in psychological science. APS Observer, 31(30/3). https://www.psychologicalscience.org/observer/preregistrationbecoming-the-norm-in-psychological-science Letöltve: 2018.12.16.

Nuzzo, R. (2014). Scientific method: Statistical errors: P values, the 'gold standard'of statistical validity, are not as reliable as many scientists assume. Nature, 506,150-152.

O'Grady, C. (2017). New papers were found through investigations into previous fraud. Ars Technica , https://arstechnica.com/science/2017/04/107-cancer-papers-retracted-due-to-peerreview-fraud/ Letöltve: 2017.09.20.

Office of University Communications, Univeristy of Nebraska-Lincoln (2014). Scientists find growing consensus: Political attitudes derive from body and mind. Online: 2014.06.31. http://newsroom.unl.edu/releases/2014/07/31/Scientists+find+growing+consensus\%3A+Political+attitudes+derive+from+body+and+mind Letöltve: 2017.09.20.

Open Science Collaboration (2012). An open, large-scale, collaborative effort to estimate the reproducibility of psychological science. Perspectives on Psychological Science, (6) 657-660.

Open Science Collaboration (2015). Estimating the reproducibility of Psychological Science. Science, 349 (6251), aac4716

Palus, Shannon (2015). Diderick Stapel now has 58 retractions. Retraction Watch, 2015.12.08. http:/ / retractionwatch.com/2015/12/08/diederik-stapel-now-has-58-retractions/ Letöltve: 2017.09.20.

Papp Z. (2004). A tudományos teljesítmény mérésének problémáiról. Magyar Tudomány, 49(2), 232-240.

Pashler, H., \& Harris, C. R. (2012). Is the replicability crisis overblown? Three arguments examined. Perspectives on Psychological Science, 7(6), 531-536.

Pashler, H., \& Wagenmakers, E. J. (2012). Editors' introduction to the Special Section on Replicability in Psychological Science: a crisis of confidence? Perspectives on Psychological Science, 7, 528-530.

Pautasso, M. (2010). A review of the worsening file drawer problem. Scientometrics, 85, 193-202.

Peterson, R. A. (2001). On the Use of College Students in Social Science Research: Insights from a Second-Order Meta-analysis. Journal of Consumer Research, 28, 450-461.

Popper, K. R. (1959). The logic of scientific discovery New York, Routledge.

Popper, K. (1959/2005). The logic of scientific discovery. London: Routledge.

Priem, J. D., Taraborelli, P., Groth, C. Neylon (2010). Altmetrics: A manifesto, 26 October 2010. http://altmetrics.org/manifesto Letöltve: 2018.05.22.

Randall, D., \& Welser, C. (2018). The irreproducability crisis of modern science. Causes, Consequences, and the Road to Reform, April 2018. Report. National Association of Scholars. Online: https:// www.nas.org/images/documents/irreproducibility_report/NAS_irreproducibilityReport. pdf Letöltve: 2018.09.21. 
Rennie, D. \& Gunsalus, C. K. (2001). Regulations on scientific misconduct: Lessons from the US experience. In S. Lock, O. Wells, \& M. J. Farthing (Eds) Fraud and misconduct in biomedical research (13-31). London: BMJ Books.

Rosenthal, R. (1979). An introduction to the file drawer problem. Psychological Bulletin, 86, 638-641.

Rosenthal, R. (1979). The file drawer problem and tolerance for null results. Psychological Bulletin, 86(3) 638.

Sanna, L. J., Chang, E. C., Miceli, P. M., \& Lundberg, K. B. (2011). RETRACTED: Rising up to higher virtues: Experiencing elevated physical height uplifts prosocial actions. Journal of Experimental Social Psychology, 47(2), 472-476.

Sarewitz, D. (2016). The pressure to publish pushes down quality. Nature, 533(7602). Online: 2016. May 11. https://www.nature.com/news/the-pressure-to-publish-pushes-down-quality1. 19887 Letöltve: 2017.09.20.

Schimmack, U. (2016). The Replicability-Index:Quantifying Statistical Research Integrity. https:/ / wordpress.com/post/replication-index.wordpress.com/920 Letöltve: 2017. 09.20.

Schimmack, U. (2016). A revised introduction to the R-Index. Replicability-Index: Improving the Replicability of Empirical Research. Online: 2016.01.31. https://replicationindex.wordpress. com/2016/01/31/a-revised-introduction-to-the-r-index Letöltve: 2017.09.20.

Schimmack, U., Heene, M., \& Kesavan, K. (2017). Reconstruction of a train wreck: How priming research went off the rails. Replicability-Index: Improving the Replicability of Empirical Research. Online: 2017 February 2. https://replicationindex.wordpress.com/2017/02/02/ reconstruction-of-a-train-wreck-how-priming-research-went-of-the-rails/Letöltve:2017.09.27.

Shea, C. (2012). The data vigilante. The Atlantic, Online: 2012 December https://www. theatlantic.com/magazine/archive/2012/12/the-data-vigilante/309172/ Letöltve: 2017.09. 20.

Simmons, J. P. \& Simonsohn, U. (2015). Power Posing: Reassessing The Evidence Behind The Most Popular TED Talk. Blog post Data Colada, Online: 2015.05.08. http://datacolada. org/37 Letöltve: 2017.09.19.

Simmons, J. P., Nelson, L. D., \& Simonsohn, U. (2011). False-positive psychology: Undisclosed flexibility in data collection and analysis allows presenting anything as significant. Psychological science, 22(11) 1359-1366.

Simmons, J. P., Nelson, L. D., \& Simonsohn, U. (2018). False-positive citations. Perspectives on Psychological Science, 13(2), 255-259.

Simmons, J. P., Nelson, L. D., \& Simonsohn, U. (2018). False-positive citations. Perspectives on Psychological Science, 13(2), 255-259.

Simons, D. J., Holcombe, A. O., \& Spellman, B. A. (2014). An introduction to registered replication reports at Perspectives on Psychological Science. Perspectives on Psychological Science, 9(5) 552-555.

Singal, J. (2015). The Case of the Amazing Gay-Marriage Data: How a graduate student reluctantly uncovered a huge scientific fraud. Science of US. http://nymag.com/scienceofus/2015/05/how-a-grad-student-uncovered-a-huge-fraud.html Letöltve: 2017.09.20.

Singal, J. (2016). Power Posing' Co-author: 'I Do Not Believe That 'Power Pose' Effects Are Real' New York Magazine, 2016.09.16. https://www.thecut.com/2016/09/power-poses-co-author-idont-think-power-poses-are-real.html Letöltve: 2017.09.20.

Smith, C. T. (2013). PsychDisclosure. org: Grassroots support for reforming reporting standards in psychology. Perspectives on Psychological Science, 8(4), 424-432.

Stapel, D. (2014). Faking science: A true story of academic fraud. Translated by Nicholas J. L. Brown. Online: 2014.12.14. https://errorstatistics.files.wordpress.com/2014/12/fakingscience-20141214.pdf Letöltve: 2017.09.20. 
Stapel, D. A., \& Lindenberg, S. (2011). Coping with chaos: How disordered contexts promote stereotyping and discrimination. Science, 332(6026) 251-253. RETRACTED

Sterling, T. D. (1959). Publication decisions and their possible effects on inferences drawn from tests of significance: Or vice versa. Journal of the American Statistical Association, 54(285), $30-34$.

Sterling, T. D., Rosenbaum, W. L., \& Weinkam, J. J. (1995). Publication decisions revisited: The effect of the outcome of statistical tests on the decision to publish and vice-versa. [Editorial Material]. American Statistician, 49(1) 108-112.

Szokolszky Á. (2018). Ezután mit gondoljunk a stanfordi börtönkísérletről? Mindset, I. rész, online: 2018.11.04. https://mindsetpszichologia.hu/2018/11/04/szokolszky-agnes-ezutanmit-gondoljunk-a-stanfordi-bortonkiserletrol-i-resz/; II. rész, online: 2018.11.09. https:// mindsetpszichologia.hu/2018/11/09/szokolszky-agnes-ezutan-mit-gondoljunk-a- stanfordibortonkiserletrol-ii-resz/; III. rész, online: 2018.11.11. https://mindsetpszichologia. hu/2018/11/11/szokolszky-agnes-ezutan-mit-gondoljunk-a-stanfordi-bortonkiserletroliii-resz/

Szúcs, D., \& Ioannidis, J. (2017). When null hypothesis significance testing is unsuitable for research: a reassessment. Frontiers in Human Neuroscience, 11, 390.

Tóth J. (2014) . Akadémiai függőség és hamisítványok: az impaktfaktor-fetisizmus egy kíséró jelenségérôl. BUKSZ, 26(3) 203-205.

Trafimow, D., \& Marks, M. (2015). Editorial //On the invalidity of statistical significance testing// Basic and Applied Social Psychology, 37(1-2) 1-2.

van der Zee, T. (2017). The Wansink Dossier: An Overview. The Skeptical Scientist blog, Online: 2017.03.21. http://www.timvanderzee.com/the-wansink-dossier-an-overview/ Letöltve: 2018. 01.21 .

Van Kolfschooten, F. (2014). Fresh misconduct charges hit Dutch social psychology. Science, 344(6184) 566-567.

Vargha A. (2016). Szignifikanciatesztek - negyven éve hibás elemzéseket végzek és téveszméket tanítok? Statisztikai Szemle, 94(4) 445-451.

Vargha, A. (2000). Matematikai statisztikai, nyelvészeti és biológiai alkalmazásokkal: felsôoktatási tankönyv. Budapest: Pólya Kiadó.

Vul, E., Harris, C., Winkielman, P., \& Pashler, H. (2009). Puzzlingly high correlations in fMRI studies of emotion, personality, and social cognition. Perspectives on Psychological Science, 4, 274-290.

Waaijer, C. J., Teelken, C., Wouters, P. F., \& van der Weijden, I. C. (2017). Competition in science: links between publication pressure, grant pressure and the academic job market. Higher Education Policy, 1-19.

Wagenmakers, E. J., Wetzels, R., Borsboom, D., van der Maas, H. L., \& Kievit, R. A. (2012). An agenda for purely confirmatory research. Perspectives on Psychological Science, 7(6), 632-638.

Wakefield, A. J., Murch, S. H., Anthony, A., Linnell, J., Casson, D. M., Malik, M., \& Valentine, A. (1998). Ileal-lymphoid-nodular hyperplasia, non-specific colitis, and pervasive developmental disorder in children. The Lancet, 351(9103) 637-641. RETRACTED.

Weir, K. (2015). A reproducability crisis? American Psychological Association. Monitor on psychology, 46(9). Online: http://www.apa.org/monitor/2015/10/share-reproducibility.aspx Letöltve: 2017.09.20.

Wesel, M. van (2016). Evaluation by citation: Trends in ublication behavior, evaluation criteria, and the strive for high impact publications. Science and Engineering Ethics, 22(1) 199-225.

Yong, E. (2012a). Replication studies: Bad copy. Nature, News, 485(7398) Online: 2012 May 16. https://www.nature.com/news/replication-studies-bad-copy-1.10634 Letöltve: 2018.01.20. 
Yong, E. (2012b). Uncertainty shrouds psychologist's resignation. Nature, News. Online: 2012 July 12. https://www.nature.com/news/uncertainty-shrouds-psychologist-s-resignation1.10968 Letöltve: 2017.09.20.

Yong, E. (2012c). Nobel laureate challenges psychologists to clean up their act. Nature, News, 485(7398) Online: 212 May 16. https:/ / www.nature.com/news/replication-studies-bad-copy -1.10634 Letöltve: 2018.01.20.

Ziliak, S. T., \& McCloskey, D. N. (2008). The cult of statistical significance. Ann Arbor: University of Michigan Press.

Zittoun, T., Gillespie, A., \& Cornish, F. (2009). Fragmentation or differentiation: questioning the crisis in psychology. Integrative Psychological and Behavioral Science, 43(2) 104-115.

\section{DYSFUNCTIONS AND REFORM MOVEMENT IN PSYCHOLOGICAL SCIENCE, IN THE BEGINNING OF THE 21ST CENTURY}

\section{SZOKOLSZKY, ÁGNES}

Negative tendencies have surfaced in psychological research in the early 2010's, although other scientific fields have also registered these problems. Such was the exposition of multiple academic frauds, the increase of publication retractions, and evidence for the extensive presence of questionable research practices. Prestigious academic journals published studies of dubious quality, and new reasons for distortions in the communication of scientific results have surfaced. The feeling of a confidentiality crisis culminated as findings of the Replication Project (2011-2015), led by Brian Nosek and others, were published. Beyond the ethical issues, awareness of the following methodological problems have stood out: lack of direct replication of results; issues with conceptual replications; neglect of negative results and related publication bias; wide spread presence of false positive results; problems with null hypothesis testing and interpretation of statistics. By the end of the 2010's psychology has developed a better understanding of the crisis. A reform movement is on the way, as a consequence, affecting research methodology, research ethics, and publication practices. In this paper I review these critical developments which have an impact on the advancement of psychological science. Individual scientists, as well as research communities need to be aware of the new recommendations and critically evaluate their own research practices.

Keywords: data manipulation, evidentiary value movement, methodological reform in psychological research, NHST, questionable research practices, replication crisis in psychology, Repliation Project, research fraud, scientific misconduct 